\section{Tectonic Geomorphology of the Karangsambung Area, Central Java, Indonesia}

Rudarsko-geološko-naftni zbornik

(The Mining-Geology-Petroleum Engineering Bulletin) UDC: $551.4: 551.3$

DOI: $10.17794 /$ rgn.2021.4.8

Professional paper

\author{
Edi Hidayat'; Dicky Muslim²; Zufialdi Zakaria3; Haryadi Permana4; Dimas Aryo Wibowo ${ }^{5}$ \\ ${ }^{1}$ Faculty of Geological Engineering, Universitas Padjadjaran, Jatinangor, Sumedang 45363, Indonesia; Research Center for Geotechnology, \\ Indonesian Institute of Sciences, Jln. Sangkuriang, Bandung 40135, Indonesia \\ ${ }^{2}$ Faculty of Geological Engineering, Universitas Padjadjaran, Jatinangor, Sumedang 45363, Indonesia \\ ${ }^{3}$ Faculty of Geological Engineering, Universitas Padjadjaran, Jatinangor, Sumedang 45363, Indonesia \\ ${ }^{4}$ Research Center for Geotechnology, Indonesian Institute of Sciences, Jln. Sangkuriang, Bandung 40135 \\ ${ }^{5}$ Research Center for Geotechnology, Indonesian Institute of Sciences, Jln. Sangkuriang, Bandung 40135
}

\begin{abstract}
Karangsambung, located in Central Java, Indonesia has complex geological conditions of the tectonic evolution of Java Island due to the subduction process of the India-Australia plate with the Eurasian plate in the Cretaceous-Paleocene. The tectonic movements in the subduction zone have resulted in diverse geological structures and rock types and impact the morphological shape of the study area. The level of tectonic activity in the study area can be determined using a tectonic geomorphological approach. A digital elevation model and geographic information systems are used for geomorphic data processing. Geological data observations were also carried out in the form of river terraces. Seven geomorphic index parameters have been calculated to determine the youngest tectonic activity through the relative tectonic activity index (IAT) of the study area: the ratio of the valley floor width to the valley height, the drainage basin asymmetry, the river gradient-length index, the basin shape index, mountain front sinuosity, drainage density, and the hypsometric integral/hypsometric curve. The IAT score is divided into four classes which are class 1 (o\%) very highly, class 2 ( $13 \%)$ highly, class $3(56 \%)$ moderately, and class $4(31 \%)$ low. The IAT shows that the research area is categorized as an active tectonic area so that the morphology formed is more influenced by tectonic activity than erosion. Geological data analysis on uplifted and deformed river terrace outcrops shows that the study area is affected by neotectonic activity.
\end{abstract}

\title{
Keywords:
}

geomorphic index; relative tectonic activity; neotectonic; Karangsambung

\section{Introduction}

Tectonic geomorphology research is very important to obtain information on neotectonic activity over a large area. The geomorphic index is an indicator that records the response to the latest deformation (neotectonic) processes, so it is widely used to identify active faults (Faghih et al., 2015; Keller and Pinter, 1996; El Hamdouni et al., 2008). Landscape and spatial data are very important for studying active tectonics because they can estimate the exact position and historical seismic records (Arrowsmith \& Zielke, 2009). Tectonic geomorphological analysis has been widely used as a parameter to measure earthquake hazard in an area (Galadini and Galli, 2000; Faghih et al., 2015; Keller and Pinter, 1996; El Hamdouni et al., 2008; Yudhicara et al., 2017; Hidayat, 2010). Large landforms of the Earth's surface resulting from the competition between uplift

Corresponding author: Edi Hidayat edih002@gmail.com and denudation processes were studied (Burbank and Anderson, 2001).

The tectonics in the research area began during Cretaceous and still continues today. In terms of regional geology, the study area has very complex geological characteristics because it is the result of the subduction process between the India-Australia Plate and the Eurasian Plate in the Cretaceous-Paleocene (Asikin, 1974). The subduction process also produces an accretion zone characterized by traces of thrust faults and a mixture of large rock blocks of various types collected in the Luk Ulo mélange complex (Asikin, 1974; Asikin et al., 1992; Suparka, 1988; Miyazaki et al., 1998; Parkinson et al., 1998; Wakita, 1994, 1997; Kadarusman et al., 2007; Clements et al., 2009; Hall, 2012). The tectonic complexity of the area affects the morphology formed. The geomorphological form can be used as a parameter to see the tectonic activity process that has occurred. The Karangsambung area describes a diverse morphology consisting of sedimentary hills, structural hills, solitary hills, plains (denudational), and the struc- 
tural morphology of the amphitheater anticline valley (Asikin et al., 1992). The formation of the anticline structure is a process of uplift and erosion associated with local scale deformation. Landforms of the Earth's surface resulting from the competition between uplift and denudation processes were studied (Burbank and Anderson, 2001). This is also thought to form the morphology of the Karangsambung amphitheater. Geomorphological parameters are the object of research to determine the relationship between tectonic activity and the resulting landscape.

This study has used seven geomorphic index parameters. The geomorphic index approach that is used in this research includes the ratio of valley floor width to valley height (Vf), drainage basin asymmetry (Af), stream length - gradient index (SL), the basin shape index (BS), mountain front sinuosity (Smf), drainage density (Dd), and the correlated hypsometric integral/hypsometric curve (HI / HC). All geomorphic index data obtained from DEM are then processed using the geographic information system (GIS) method. This research also discusses the relationship and influence of each geomorphic index on the research area's tectonic activity. In addition to the geomorphic index, geological parameters in the form of geological structures, rock types, and river terraces are used to complete this research analysis. The research objective was to determine tectonic activity based on geomorphological appearance through the geomorphic index approach.

\section{Geological setting}

The Karangsambung physiography is part of the Southern Serayu Mountain (Tjia, 1966; Asikin, 1974; Suparka, 1986; Wakita, 1994; Harsolumakso, 1996; Satyana, 2002; Prasetyadi, 2006, 2007). The main anticline, known as the Karangsambung anticline with the east-west axis folding, induces Paleogene rock and exposes the Pre-Paleogene rock of Luk Ulo Complex (Prasetyadi, 2006) (see Figure 1c). Based on the direction of the fold axis, it can be seen that the main stress direction of compression forming the fold structure is North-South trending (see Figure 1a).

The study area is considered the boundary for Javanese subduction during the Cretaceous-Paleocene (Asikin, 1974; Clements et al., 2009; Hall, 2012; Parkinson et al., 1998; Wakita, 2000). The subduction process then stopped due to the Gondwana microcontinent's collision with the Sundaland section on the eastern and southeastern edges of the Upper Cretaceous (Smyth et al., 2007). After that, a new subduction zone was formed in the south that began in the Middle Eocene and was followed by olistostromes' formation (Karangsambung Formation and Totogan Formation) in the Late Eocene Miocene (Prasetyadi et al., 2006).

The oldest rock exposed in this area is the Pre-Paleogene rock unit known as the Luk Ulo Melange Complex, which consists of a tectonic mixture of metamorphic rock blocks (eclogite, glaucophane, blueschist, amphibolite, serpentinite, greenschist), mafic and ultramafic igneous rocks (gabbro, diabase, basalt), pelagic and hemipelagic deep-sea sedimentary rocks (chert, red claystone) embedded in the claystone matrix (Asikin, 1974; Asikin et al., 1992; Suparka, 1988; Wakita, 2000; Kadarusman et al., 2007; Miyazaki et al., 1998; Parkinson et al., 1998). The radiolaria age dating on chert sedimentary rocks shows that the deposition age starts from Lower-Upper Cretaceous and then the accretion process begins at Upper Cretaceous - Paleocene (Wakita et al., 1994). These sedimentary rocks are carried into the subduction zone due to oceanic plates' movement and then form a tectonic mélange (Melange Luk Ulo Complex) (see Figure 1b and Figure 1c).

The Melange Luk Ulo complex is covered with unconformities by the Karangsambung Formation and the Totogan Formation. The Karangsambung and Totogan formations generally consist of sedimentary mixtures of fragments and blocks (olistolite), such as sandstones, siltstone, conglomerates, nummulitic limestone, lava in the clay basement and are interpreted as olistostrome deposits (Asikin, 1974; Handayani et al., 2021). Furthermore, the younger Neogene rocks are deposited, namely the Waturanda Formation and the Penosogan Formation. Deposits over the Karangsambung Formation and Totogan Formation are in conformity with a series of volcano-clastic turbidite sediments in the Waturanda Formation aged Neogene siliciclastic-carbonate Penosogan Formation aged Neogen (Asikin et al., 1992). Texture differences, grain size, and variations in layer thickness in the Waturanda Formation and Penosogan Formation indicate changes in sedimentary flow regimes (see Figure 1b).

In general, the Karangsambung area structure consists of three main structural directions. The first direction of the structure is the southwest-northeast direction, indicated by the general direction of the boudin structure's long axis, developed in Pre-Paleogene rock groups (Harsolumakso et al., 1995). The other structure in the East-West is indicated by the general direction that the fold structure and thrust fault developed in the Neogen rock and in a north-south direction of the faults that cut Pre-Paleogene and Neogen rocks (Asikin et al., 1992) (see Figure 1c). The exposure of the old rock complex melange Luk Ulo Karangsambung was due to a maximum uplift and the mechanism of the maximum impact as a result of the confluence of two large horizontal faults moving opposite each other, namely the Muria Kebumen Fault (southwest-northeast, Meratus direction, Sinistral) and the Pamanukan - Cilacap Fault (northwestsoutheast, Sumatra Direction, Dextral) intersects the central part of Java Island and meets in the southern part of Central Java during the Paleogene orogenesis period (Satyana, 2002) (see Figure 2). Overall, the geology of the Karangsambung area has been mapped systemati- 


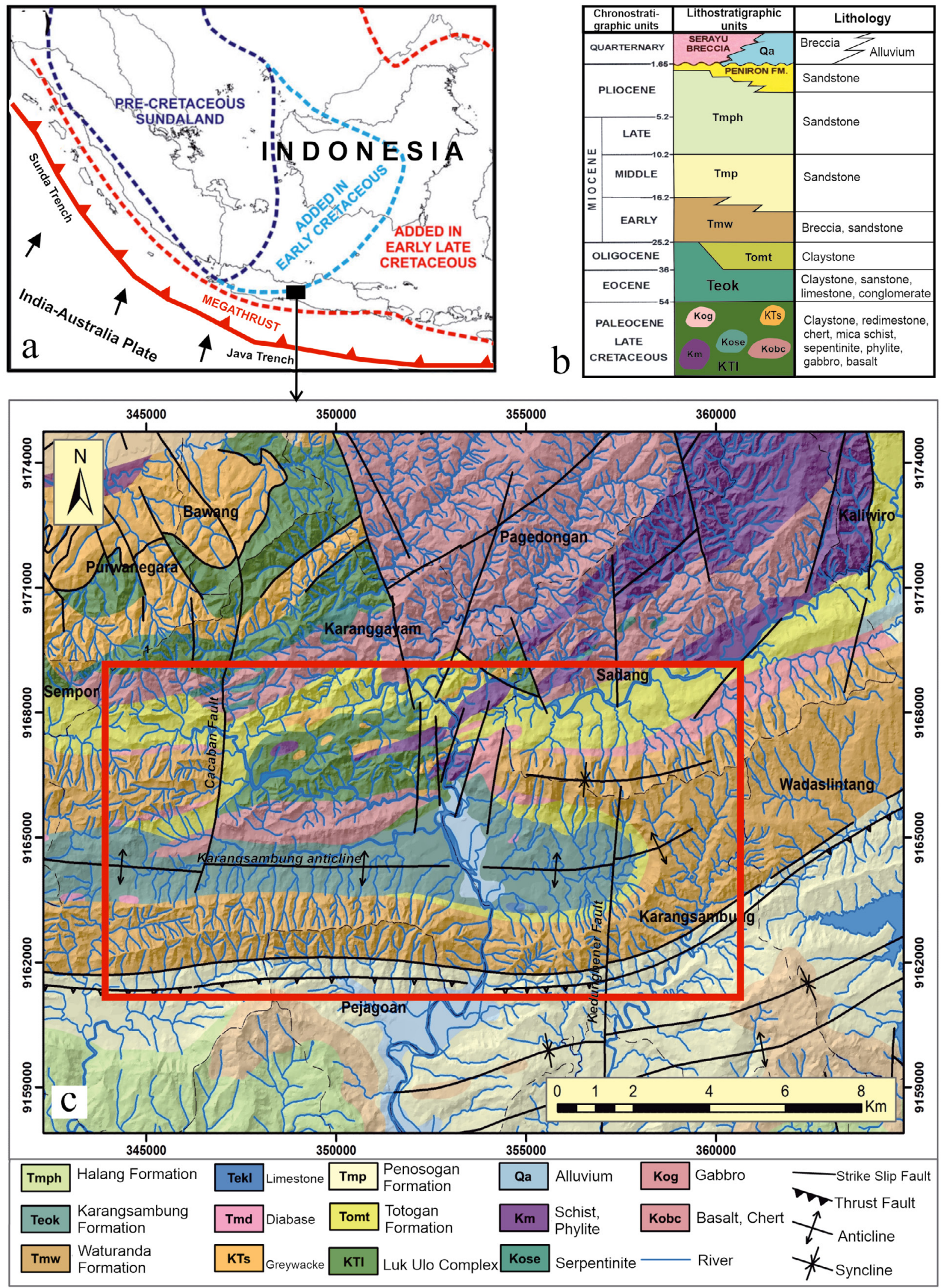

Figure 1: a) The location of the study area, Karangsambung was located at the subduction zone, where the Indo-Australian plate subducts with the Sunda microplate along the Java-Meratus suture. (modified: Hall, 2012; Soeria-Atmadja et al., 1994; Wakita, 200o; Sribudiyani et al., 2003; Handayani et al., 2021). b) stratigraphic column, c) Geological map of Karangsambung Complex shows the distribution of formations (Condon et al., 1996; Askin et al., 1992). The red box is the study area. 


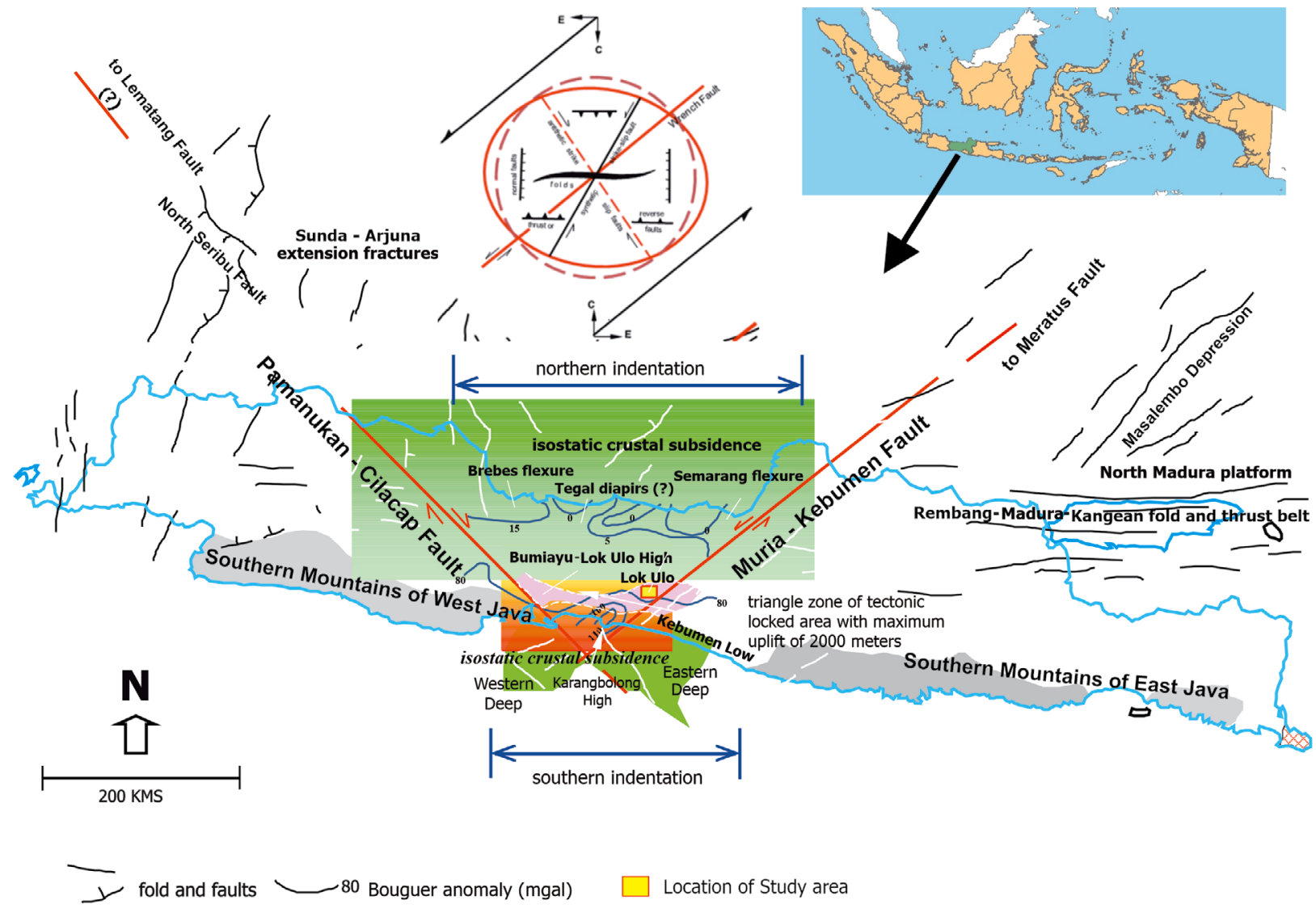

Figure 2: Central Java has been flanked by couple of major faults of Kebumen-Muria and Pamanukan-Cilacap, opposing on trends and slips. Within the triangle of faults, crustal masses were dragged and to be more uplifted southward due to the slips of faults (Satyana, 2002).

cally by Condon et al. (1996) in the north and by Asikin et al. (1992) in the south (see Figure 1b and Figure 1c).

\section{Methods}

The geomorphology index is one method of studying active tectonic areas that can give knowledge of relatively rapid levels of active tectonic deformation (Bull and McFadden, 1977; Keller and Pinter, 1994, 2002; Faghih, 2015). The research used seven geomorphic index parameters: 1) the ratio of valley floor width to valley height (Vf), 2) drainage basin asymmetry (AF), 3) stream length - gradient index (SL), 4) the basin shape index (BS), 5) mountain front sinuosity (Smf), 6) drainage density (Dd), and 7) the correlated hypsometric integral/hypsometric curve (HI/HC). Morphotectonic variable calculations using geographic information systems (GIS) based Arcgis 10.1 software from topographic maps at a scale of 1:25000, DEM with a spatial resolution of 30 m (URL 1) (see Figure 3 and Figure 4).

\subsection{The ratio of the valley floor and valley height $(\mathrm{Vf})$}

The ratio of the valley floor and valley height (Vf) is calculated to determine the geometry of the valley asso- ciated with tectonics or erosion. The tectonic activity of a fault affects the shape of a river valley and the presence of deformations in the alluvial with an asymmetric fold (Khayingshing, 2015). The high Vf value is associated with a low uplifting rate so that the river will cut widely at the bottom of the valley, and the valley shape will expand even further.

$$
V f=2 V_{f w} /\left(E_{l d}-E_{s c}\right)+\left(E_{r d}-E_{s c}\right)
$$

Where:

$V f$ - the ratio of the valley floor and valley height,

$V_{f w}$ - the valley's width (m),

$E_{l d}$ - the valley's left (m),

$E_{r d}$ - right elevation (m),

$E_{s c}$ - the valley base elevation (m).

This index differentiates between valleys with a wide floor relative to the height of valley walls with a "U" shape compared to narrow, steep valleys with a "V" shape. Valleys with a U shape generally have high values of Vf, whereas V-shaped valleys have relatively low values. Since uplift is associated with incision, the index is thought to be a surrogate for active tectonics, where low values of $\mathrm{Vf}$ are associated with higher rates of uplift and incision. The index is a measure of incision and not uplift; but in an equilibrium state, incision and uplift are nearly matched (El Hamdouni et al., 2008). 


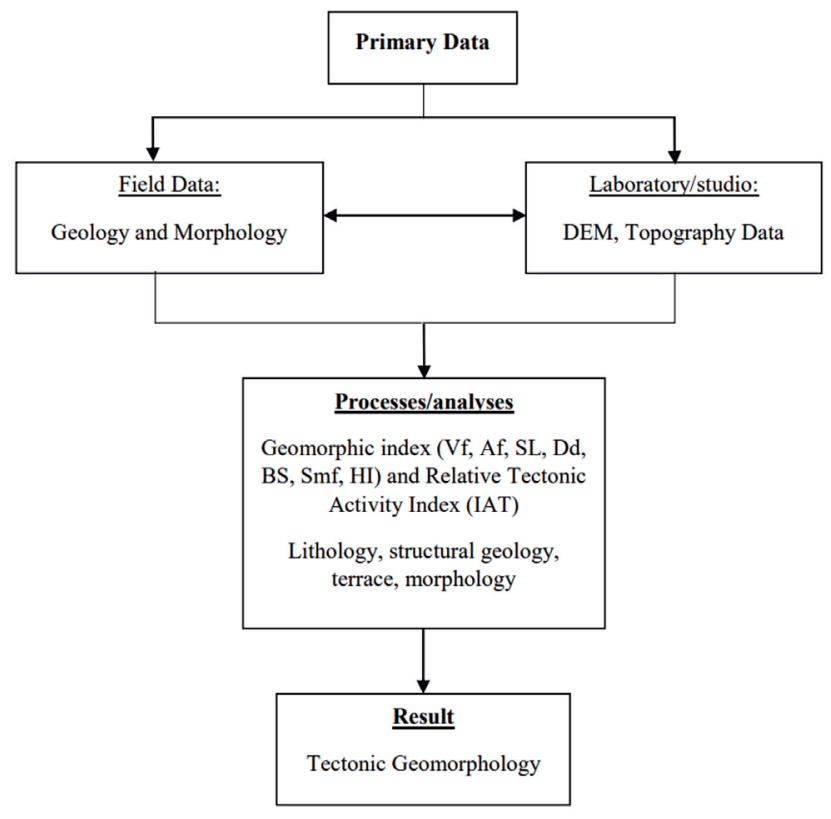

Figure 3: Workflow methodology of this research

\subsection{Streams - gradients index (SL)}

The value of SL is strongly influenced by the slope of the river changes (channel slope). These SL's sensitivity can be used to evaluate the relationship between active tectonic, bedrock, and topography resistance (Keller and Pinter 1996). Active tectonics in a region will be indicated by a high value of the SL index.

$$
S L=(\Delta H / \Delta L) \times L
$$

Where:

$S L$ - the stream length-gradient index,

$\Delta H$ - the elevation difference between the upper and the lower part of the reach $(\mathrm{m})$,

$\Delta L$ - the length of the reach (m),

$L \quad$ - the channel length from the divide to the midpoint of the channel reach for which the index is calculated $(\mathrm{m})$.

The SL value index can distinguish a type of uplift low tectonic, medium, and high (Keller and Pinter, 1996).

\subsection{Drainage basin asymmetry (AF)}

The value of $\mathrm{AF}$ is very important to determine the effect of active tectonics in the research area. The value of AF reflects the asymmetry of a sub-watershed, which is influenced by tectonic processes. The geometry of sub-watersheds can be described both qualitatively and quantitatively. Patterns and geometry sub-watershed can provide information on tectonic activity. The change in position of a river's flow in a sub-watershed is due to an inclination where the sub-watershed is influenced by an active tectonic (Singh, 2016). The asymmetry factor (AF) is a quantitative analysis of sub-watershed for de- tecting tectonic tilting on the scale of both small and large.

$$
A F=100\left(\frac{A_{r}}{A_{t}}\right)
$$

Where:

$A F$ - the asymmetry factor index,

$A_{r}$ - the basin area to the right of the stream (looking downstream) $\left(\mathrm{km}^{2}\right)$,

$A_{t}$ - the total area of the drainage sub-watershed $\left(\mathrm{km}^{2}\right)$.

The $\mathrm{AF}$ value indicates a value of 50 , so the area has a low tilt sub-watershed. If the AF value is 50 , then the area has a small sub-watershed tilting. It indicates that tectonic activity is relatively stable. If the AF value is greater or less than 50 , then tilting occurs due to tectonic activity (EI Hamdouni et al., 2008).

\subsection{Mountain front sinuosity $(\mathrm{Smf})$}

Several studies have suggested that a low Smf value $(\mathrm{Smf}<1.4)$ is an indication of active tectonics (El-Hamdouni et al., 2008). Smf is an index that reflects the balance between erosion and tectonic activity that tends to cut along the ridges of the mountain front that directly produce the mountain front and are associated with active fault zones.

$$
\operatorname{Smf}=\frac{L_{m f}}{L_{s}}
$$

Where:

$S m f$ - the mountain front sinuosity,

$L_{m f}$ - the length of the mountain front along the break of slope $(\mathrm{km})$,

$L_{s} \quad$ - the length of a straight-line along the same sector of the mountain front $(\mathrm{km})$.

Low Smf values are associated with active tectonics and uplifting directly. If the lifting speed decreases, the erosion process will cut the mountain face irregularly, and the Smf value will increase.

\subsection{Basin shape index (BS)}

Horizontal projections of the basin can be explained by the basin shape index or extension ratio (BS) defined as (Cannon 1976; Ramirez-Herrera, 1998; Faghih 2015):

$$
B S=B l / B w
$$

Where:

$B S$ - the drainage basin shape index,

$B l$ - the length of the basin measured from the highest point $(\mathrm{km})$,

$B w$ - the width of the sub-watershed measured the widest $(\mathrm{km})$.

A relatively tectonic sub-watershed has a propensity to lengthen, following topographical tilt (Bull and Mc- 
Fadden, 1977). With sustained evolution or inactive tectonic activity, the initial elongated shape tends to evolve into a more circular shape (Bull and McFadden, 1977).

\subsection{Drainage density (Dd)}

The value of $\mathrm{Dd}$ is a geomorphic index related to the density of tributaries in a watershed. The value of Dd is a parameter that reflects the tectonic activity of an area. Previous studies did not use the Dd value as a calculated parameter. An area that is deformed by tectonic activity will be reflected by the physically erosive characteristic of lithology, thus producing a drainage density that is relatively higher than stable areas (Sukiyah, 2017). The drainage density is an index number that can identify the many tributaries contained in a watershed. Drainage density (Dd) is a ratio of the length of a river segment to the size of a watershed or a sub-watershed. The higher the Dd value, the more drainage of rivers occupies watershed or sub-watershed. Horton (1945) has established a new set of drainage density (Dd):

$$
D d=\frac{\sum L}{A}
$$

Where:

$D d$ - the drainage density,

$\sum L$ - the total length of the river $(\mathrm{km})$,

$A$ - the watershed area or sub-watershed $\left(\mathrm{km}^{2}\right)$.

\subsection{Hypsometric Integral (HI)}

The hypsometric integral (HI) is an index that describes the altitude distribution of a landscape area (Strahler, 1952). A simple equation that might be used to calculate the index (Keller and Pinter, 2002) is:

$$
H I=\left(h_{\text {mean }}-h_{\text {min }}\right) /\left(h_{\text {max }}-h_{\text {min }}\right)
$$

Where:

$H I$ - the hypsometric integral,

$h_{\max }$ - the maximum elevation,

$h_{\text {min }}$ - the minimum elevation,

$h_{\text {mean }}$ - mean elevations respectively.

This equation will be reflected in the form of a hypsometric curve. The hypsometric curve can provide an overview of the land's shape based on its pattern, namely land in the young, middle, and old stages (Keller and Pinter, 1996). The altitude values required for the calculation are obtained from a digital elevation model (DEM). Integral hypsometry is not directly related to active tectonic relativity but needs to be correlated with other geological conditions. This HI index is almost the same as the SL index, greatly influenced by rock resistance. HI values are not directly related to tectonic activity. High values of HI could also result from a recent incision into a young geomorphic surface produced by deposition (El Hamdouni et al., 2008).

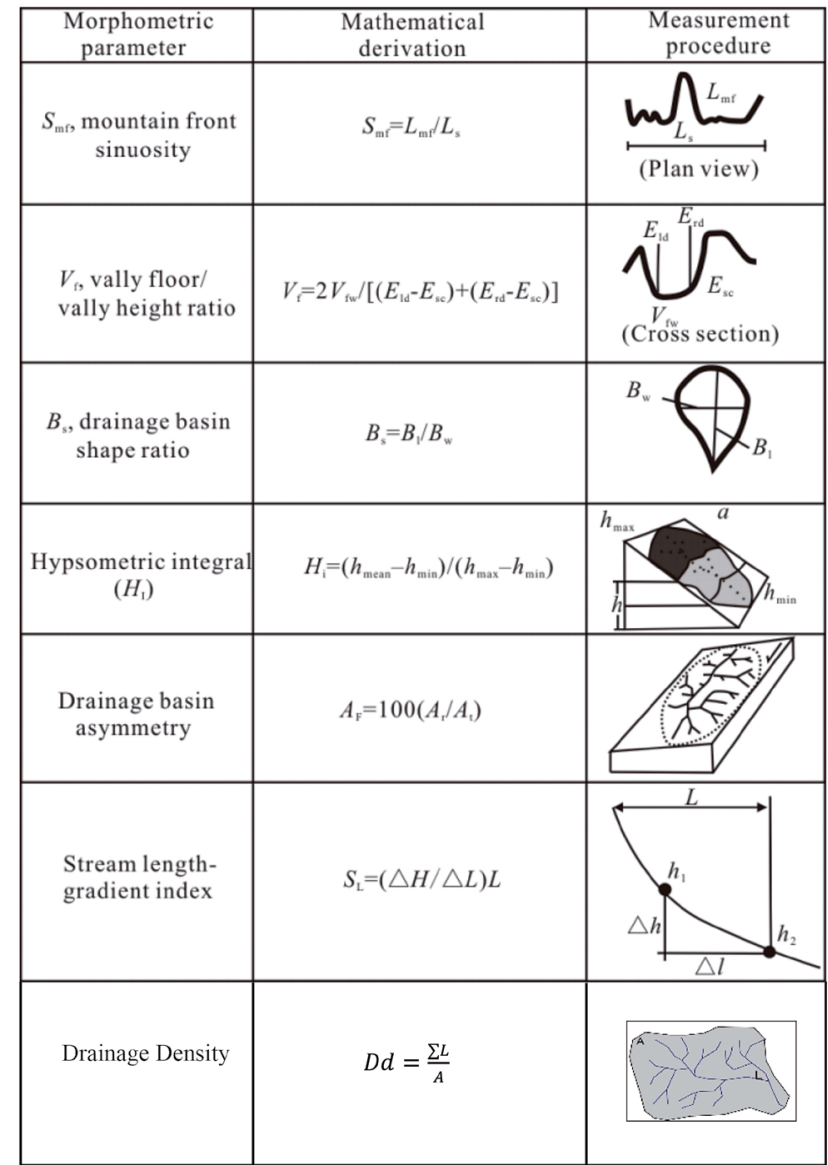

Figure 4: Summary of morphotectonic indices used in tectonic analysis activities in the study area (modified after Faghih, 2015; Keller and Pinter, 2002; Ramirez-Herrara, 1998; El Hamdouni, 20o8; Bull and McFadden, 1977; Horton, 1945)

\subsection{Relative Tectonic Activity Index (IAT)}

All geomorphic index calculation results are analyzed and correlated to obtain information related to the tectonic activity level, reflected in the study area's geomorphological formation. The IAT is obtained from the mean of the different classes of the geomorphic index parameter $(S / n)$.

Where:

$$
I A T=S / n
$$

$I A T$ - the relative tectonic activity index,

$S$ - the sum of the class values of each geomorphic index,

$n$ - the sum of the geomorphic indexes.

The $\mathrm{S} / \mathrm{n}$ value in the study used seven geomorphic indices. Drainage density is used in this study, because drainage density also affects rock resistance so that it has an impact on the IAT. The mean values $(\mathrm{S} / \mathrm{n})$ are grouped into four classes of tectonic activity (IAT), of which class 1 is very high with $\mathrm{S} / \mathrm{n}$ values between 1 and 1.5; class 2 is a high tectonic activity with $\mathrm{S} / \mathrm{n}$ values of 1.5 to 2; class 3 active medium tectonics with $\mathrm{S} / \mathrm{n} 2$ to 2.5 , 
and class 4 is low active tectonics with a value of $\mathrm{S} / \mathrm{n}>$ 2.5 (El-Hamdouni et al., 2008).

\section{Results}

\subsection{The geomorphic indexes}

The approach of this paper has been to use data extracted from geomorphic indices as a quantitative method to provide evidence of variations in tectonic activity. Results relating to variations in the geomorphic indices are presented in this section.

\subsubsection{The ratio of the valley floor and valley height (Vf)}

Vf is calculated to determine the geometry of the valley associated with tectonics or erosion. Vf is classified into three classes: class $1(\mathrm{Vf}<0.5)$, class $2(0.5-1)$ and class $3(\mathrm{Vf}>1)$ (El Hamdouni et al., 2008) are shown in Table 1 and Figure 5. The Vf values of the research area range from 0.25 to 12.75 . The Vf value is relatively low for V-shaped valleys and relatively high for U-shaped valleys. High Vf values dominate the eastern part of the research area.

Meanwhile, classes 1 and 2 are scattered in the northern and southern parts of the study area. The high Vf value in the eastern part of the research area is strongly influenced by a similar lithology, namely andesite breccias. Meanwhile, the low Vf value with a V-shaped valley is influenced by lithology and geological structures in faults and fractures. The lithology is composed of claystone matrix and igneous rock as melange block in the Melange Luk Ulo Formation.

\subsubsection{Streams - gradients index (SL)}

The SL values calculated along streams and rivers using a DEM with a spatial resolution of $30 \mathrm{~m}$ with GIS processing resulted in an average value for each subwatershed. The research area showed that the SL values ranged from 66.5 to 734.5 . The values are classified into three classes: class 1 (SL> 500), class 2 (300 - 500), and class 3 ( $\mathrm{SL}<300$ ), according to El-Hamdouni et al. (2008), which is shown in Figure 6.

Table 1: Vf (ratio of valley floor width to valley height) values calculated in the 52 sub-watershed

\begin{tabular}{|c|c|c|c|}
\hline No. Sub-watershed & Lithology & Vf & Class \\
\hline 1 & Breccia & 2.88 & 3 \\
\hline 2 & Breccia & 12.75 & 3 \\
\hline 3 & Breccia & 4.87 & 3 \\
\hline 4 & Breccia & 9.15 & 3 \\
\hline 5 & Breccia & 12.63 & 3 \\
\hline 6 & Breccia & 12.63 & 3 \\
\hline 7 & Breccia & 1.33 & 3 \\
\hline 8 & Breccia & 3.48 & 3 \\
\hline 9 & Breccia & 4.63 & 3 \\
\hline 10 & Breccia & 6.45 & 3 \\
\hline 11 & Breccia & 1.07 & 3 \\
\hline 12 & Breccia & 9.09 & 3 \\
\hline 13 & Breccia & 2.74 & 3 \\
\hline 14 & Breccia & 3.04 & 3 \\
\hline 15 & Breccia & 2.33 & 3 \\
\hline 16 & Breccia & 2.31 & 3 \\
\hline 17 & Breccia & 1.31 & 3 \\
\hline 18 & Breccia & 1.07 & 3 \\
\hline 19 & Breccia & 0.55 & 2 \\
\hline 20 & Breccia & 0.82 & 2 \\
\hline 21 & Breccia & 0.81 & 2 \\
\hline 22 & Breccia & 0.82 & 2 \\
\hline 23 & Breccia & 0.64 & 2 \\
\hline 24 & Breccia & 3.75 & 3 \\
\hline 25 & Breccia & 1.57 & 3 \\
\hline 26 & Breccia & 13.03 & 3 \\
\hline
\end{tabular}

\begin{tabular}{|c|c|c|c|}
\hline No. Sub-watershed & Lithology & Vf & Class \\
\hline 27 & Breccia & 5.93 & 3 \\
\hline 28 & Breccia & 0.66 & 2 \\
\hline 29 & Breccia & 3.30 & 3 \\
\hline 30 & Breccia & 0.87 & 2 \\
\hline 31 & Breccia & 0.25 & 1 \\
\hline 32 & Breccia & 0.35 & 1 \\
\hline 33 & Breccia & 1.19 & 3 \\
\hline 34 & Breccia & 0.47 & 1 \\
\hline 35 & Breccia & 0.49 & 1 \\
\hline 36 & Breccia & 4.60 & 3 \\
\hline 37 & Breccia & 1.60 & 3 \\
\hline 38 & Breccia & 2.93 & 3 \\
\hline 39 & Breccia & 0.35 & 1 \\
\hline 40 & Breccia & 0.85 & 2 \\
\hline 41 & Diabase & 2.20 & 3 \\
\hline 42 & Diabase & 3.05 & 3 \\
\hline 43 & Diabase & 0.50 & 1 \\
\hline 44 & Claystone & 1.83 & 3 \\
\hline 45 & Breccia & 1.39 & 3 \\
\hline 46 & Breccia & 0.98 & 2 \\
\hline 47 & Gabbro & 0.37 & 1 \\
\hline 48 & Gabbro & 0.32 & 1 \\
\hline 49 & Gabbro, basalt & 0.25 & 1 \\
\hline 50 & Claystone & 1.28 & 3 \\
\hline 51 & Breccia & 0.88 & 2 \\
\hline 52 & Schist, phylite & 0.41 & 1 \\
\hline
\end{tabular}




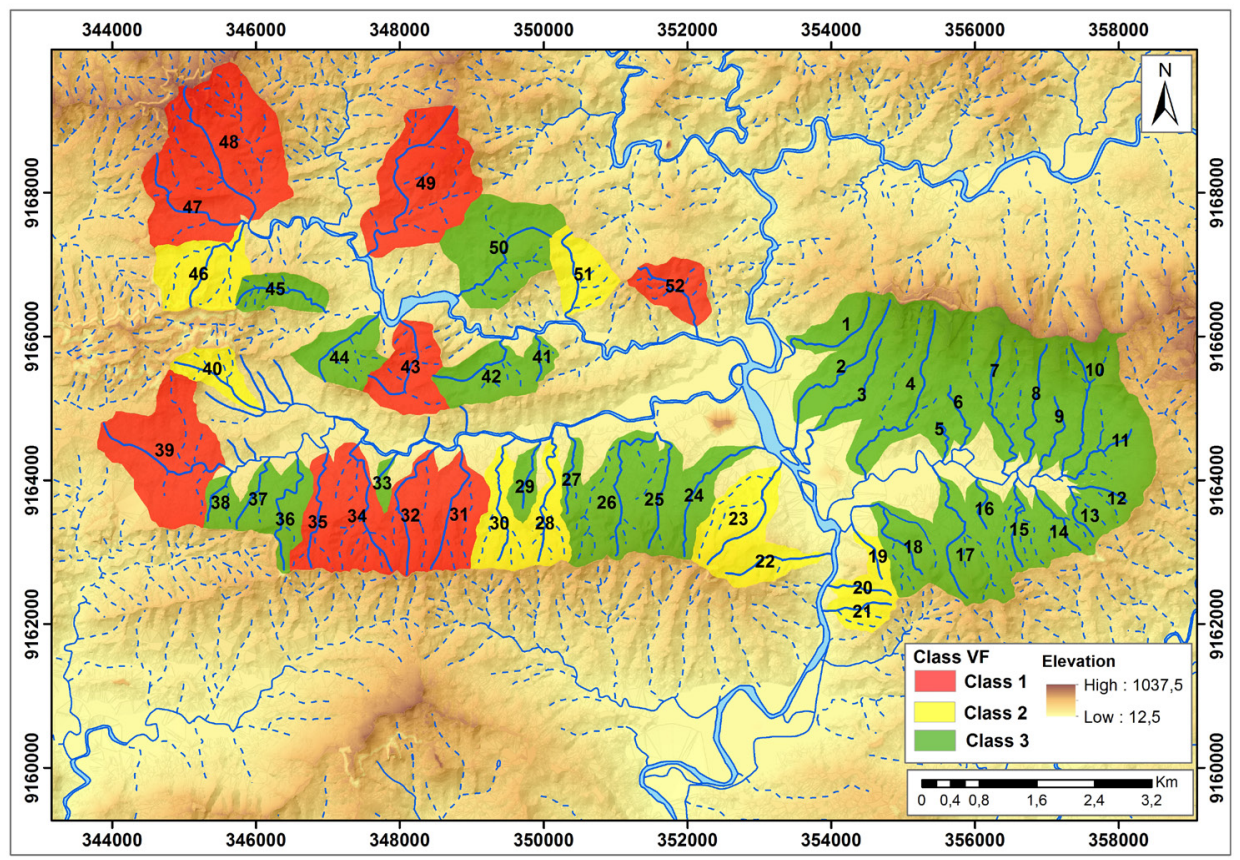

Figure 5: Classification of sub-basins of the study area based on the measurement of the ratio of valley floor width to valley height (Vf) indices

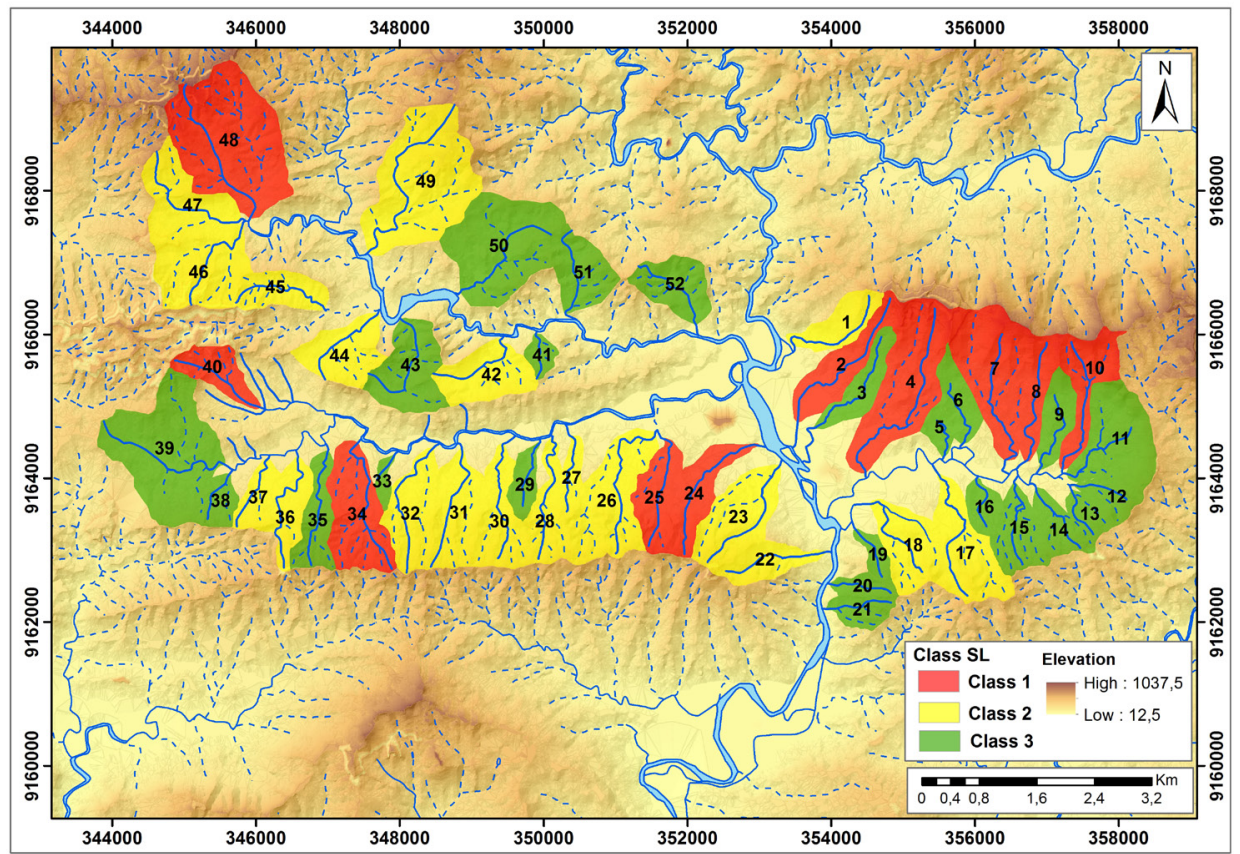

Figure 6: Classification of sub-watershed of the study area based on the measurement of the streams - gradients index (SL) indices

\subsubsection{Drainage basin asymmetry (AF)}

The sub-watershed asymmetry can be seen from the asymmetry of the sub-watershed shape due to the different tilt. AF values range from 22.29 to 79.49 . AF values are divided into three classes: class 1 ( $\mathrm{AF}>15)$, class 2: (7-15) and class $3(\mathrm{AF}<7) .70 \%$ of the sub-watershed studied formed asymmetry, as shown in Table 2 and Figure 7.

\subsubsection{Mountain front sinuosity (Smf)}

Smf represents a balance between erosive processes tending to erode a mountain front, making it more sinuous through streams that cut laterally and into the front and active vertical tectonics that tend to produce straight mountain fronts, often coincidental with active faults or folds (Bull and McFadden, 1977). A higher Smf value 
Table 2: AF (drainage basin asymmetry) values calculated in the 52 sub-watershed

\begin{tabular}{|c|c|c|c|c|c|c|}
\hline $\begin{array}{l}\text { No. } \\
\text { Sub- } \\
\text {-water- } \\
\text { shed }\end{array}$ & $\begin{array}{l}\mathbf{A r} \\
\left(\mathbf{k m}^{2}\right)\end{array}$ & $\begin{array}{l}\text { Al } \\
\left(\mathbf{k m}^{2}\right)\end{array}$ & $\begin{array}{l}\text { At } \\
\left(\mathbf{k m}^{2}\right)\end{array}$ & AF & AF-50 & Class \\
\hline 1 & 0.394 & 0.172 & 0.566 & 69.634 & 19.634 & 1 \\
\hline 2 & 0.410 & 0.410 & 0.820 & 50.010 & 0.010 & 3 \\
\hline 3 & 0.212 & 0.327 & 0.539 & 39.367 & -10.633 & 2 \\
\hline 4 & 1.093 & 0.621 & 1.713 & 63.780 & \begin{tabular}{|l|}
13.780 \\
\end{tabular} & 2 \\
\hline 5 & 0.135 & 0.072 & 0.207 & 65.267 & 15.267 & 1 \\
\hline 6 & 0.195 & 0.260 & 0.455 & 42.930 & -7.070 & 2 \\
\hline 7 & 0.924 & 0.667 & 1.590 & 58.076 & 8.076 & 2 \\
\hline 8 & 0.275 & 0.281 & 0.556 & 49.415 & -0.585 & 3 \\
\hline 9 & 0.221 & 0.269 & 0.490 & 45.172 & -4.828 & 3 \\
\hline 10 & 0.341 & 0.476 & 0.818 & 41.738 & -8.262 & 2 \\
\hline 11 & 0.592 & 0.646 & 1.238 & 47.834 & -2.166 & 3 \\
\hline 12 & 0.143 & 0.208 & 0.351 & 40.771 & -9.229 & 2 \\
\hline 13 & 0.197 & 0.051 & 0.248 & 79.476 & 29.476 & 1 \\
\hline 14 & 0.196 & 0.267 & 0.464 & 42.375 & -7.625 & 2 \\
\hline 15 & 0.342 & 0.310 & 0.652 & 52.443 & 2.443 & 3 \\
\hline 16 & 0.145 & 0.152 & 0.297 & 48.873 & -1.127 & 3 \\
\hline 17 & 0.736 & 0.359 & 1.096 & 67.198 & 17.198 & 1 \\
\hline 18 & 0.478 & 0.350 & 0.827 & 57.730 & 7.730 & 2 \\
\hline 19 & 0.111 & 0.083 & 0.194 & 57.223 & 7.223 & 2 \\
\hline 20 & 0.122 & 0.102 & 0.224 & 54.275 & 4.275 & 3 \\
\hline 21 & 0.116 & 0.229 & 0.345 & 33.629 & -16.371 & 1 \\
\hline 22 & 0.279 & 0.252 & 0.531 & 52.466 & 2.466 & 2 \\
\hline 23 & 0.317 & 0.738 & 1.055 & 30.056 & -19.944 & 1 \\
\hline 24 & 0.337 & 0.408 & 0.745 & 45.300 & -4.700 & 2 \\
\hline 25 & 0.327 & 0.390 & 0.717 & 45.593 & -4.407 & 2 \\
\hline 26 & 0.528 & 0.872 & 1.400 & 37.715 & -12.285 & 2 \\
\hline
\end{tabular}

\begin{tabular}{|c|c|c|c|c|c|c|}
\hline $\begin{array}{l}\text { No. } \\
\text { Sub- } \\
\text {-water- } \\
\text { shed }\end{array}$ & $\begin{array}{l}\mathrm{Ar} \\
\left(\mathbf{k m}^{2}\right)\end{array}$ & $\begin{array}{l}\mathrm{Al} \\
\left(\mathrm{km}^{2}\right)\end{array}$ & $\begin{array}{l}\mathbf{A t} \\
\left(\mathbf{k m}^{2}\right)\end{array}$ & $\mathbf{A F}$ & AF-50 & Class \\
\hline 27 & 0.186 & 0.087 & 0.274 & 68.094 & 18.094 & 1 \\
\hline 28 & 0.408 & 0.245 & 0.654 & 62.477 & 12.477 & 2 \\
\hline 29 & 0.114 & 0.193 & 0.307 & 37.224 & -12.776 & 2 \\
\hline 30 & 0.397 & 0.432 & 0.829 & 47.887 & -2.113 & 3 \\
\hline 31 & 0.623 & 0.320 & 0.943 & 66.097 & 16.097 & 1 \\
\hline 32 & 0.625 & 0.282 & 0.907 & 68.899 & 18.899 & 1 \\
\hline 33 & 0.093 & 0.033 & 0.126 & 73.886 & 23.886 & 1 \\
\hline 34 & 0.267 & 0.923 & 1.190 & 22.436 & -27.564 & 1 \\
\hline 35 & 0.317 & 0.282 & 0.599 & 52.971 & 2.971 & 3 \\
\hline 36 & 0.380 & 0.233 & 0.612 & 62.005 & 12.005 & 2 \\
\hline 37 & 0.268 & 0.099 & 0.367 & 73.050 & 23.050 & 1 \\
\hline 38 & 0.213 & 0.075 & 0.288 & 73.917 & 23.917 & 1 \\
\hline 39 & 0.986 & 1.210 & 2.196 & 44.908 & -5.092 & 3 \\
\hline 40 & 0.028 & 0.033 & 0.061 & 45.372 & -4.628 & 3 \\
\hline 41 & 0.081 & 0.1876 & 0.269 & 30.218 & -19.782 & 1 \\
\hline 42 & 0.618 & 0.8582 & 1.476 & 41.846 & -8.154 & 2 \\
\hline 43 & 0.637 & 0.9957 & 1.632 & 39.006 & -10.994 & 2 \\
\hline 44 & 0.524 & 0.8146 & 1.339 & 39.162 & -10.838 & 2 \\
\hline 45 & 0.273 & 0.5796 & 0.852 & 32.010 & -17.990 & 1 \\
\hline 46 & 0.539 & 1.1465 & 1.685 & 31.970 & -18.030 & 1 \\
\hline 47 & 0.615 & 1.1415 & 1.756 & 35.005 & -14.995 & 1 \\
\hline 48 & 0.712 & 2.4804 & 3.192 & 22.298 & -27.702 & 1 \\
\hline 49 & 0.737 & 2.2760 & 3.013 & 24.454 & -25.546 & 1 \\
\hline 50 & 1.127 & 1.8009 & 2.928 & 38.499 & -11.501 & 2 \\
\hline 51 & 0.277 & 0.7486 & 1.025 & 26.976 & -23.024 & 1 \\
\hline 52 & 0.299 & 0.6992 & 0.998 & 29.930 & -20.070 & 1 \\
\hline
\end{tabular}

$(>3)$ is usually associated with inactive tectonic areas. Smf measurements in 52 sub-watersheds using the DEM $30 \mathrm{~m}$ and obtained three values that became the basis for class division according to the level of tectonic activity: class 1 (1.0-1.1), class $2(1.1-1.5)$ and class $3(>1.5)$ as shown in Table 3 and Figure 8.

\subsubsection{Basin shape index (BS)}

High values of BS are associated with the elongated geometric shape of the watershed, generally associated with relatively higher tectonic activity. A low BS value indicates a more circular shape of the watershed, commonly related to low tectonic activity. Therefore, BS can reflect the level of tectonic activity. The value of BS is calculated using a DEM and classified into three classes: class $1(\mathrm{BS}>4)$, class $2(3-4)$, and class $3(\mathrm{BS}<3)$. The $\mathrm{BS}$ values range from 0.81 to 4.30 . More than $3 / 4$ of the studied sub-watershed belong to classes 2 and 3 with lower BS values, while class 1 with high BS values cover about $1 / 4$ of the study area so the shape of the sub-watershed is more circular Table 4 and Figure 9.

\subsubsection{Drainage density (Dd)}

Dd value will be included as a new parameter to determine the tectonic activity value in the research area. Drainage density is an index number that can indicate the number of tributaries in a watershed. Flow density is an index number that can indicate the number of tributaries in a watershed. Drainage density (Dd) is the ratio between the total length of river segments to a watershed or sub-watershed area. The higher the $\mathrm{Dd}$ value, the more drainage density that occupies the watershed or sub-watershed. Sukiyah (2009) divides drainage density (Dd) into six grades, grade 1 is very rough (0-1.379) to grade 2 is rough (1.380-2.759) in class 3 , grade 3 is medium (2.760-4.139) to grade 4 is smooth (4.140- 


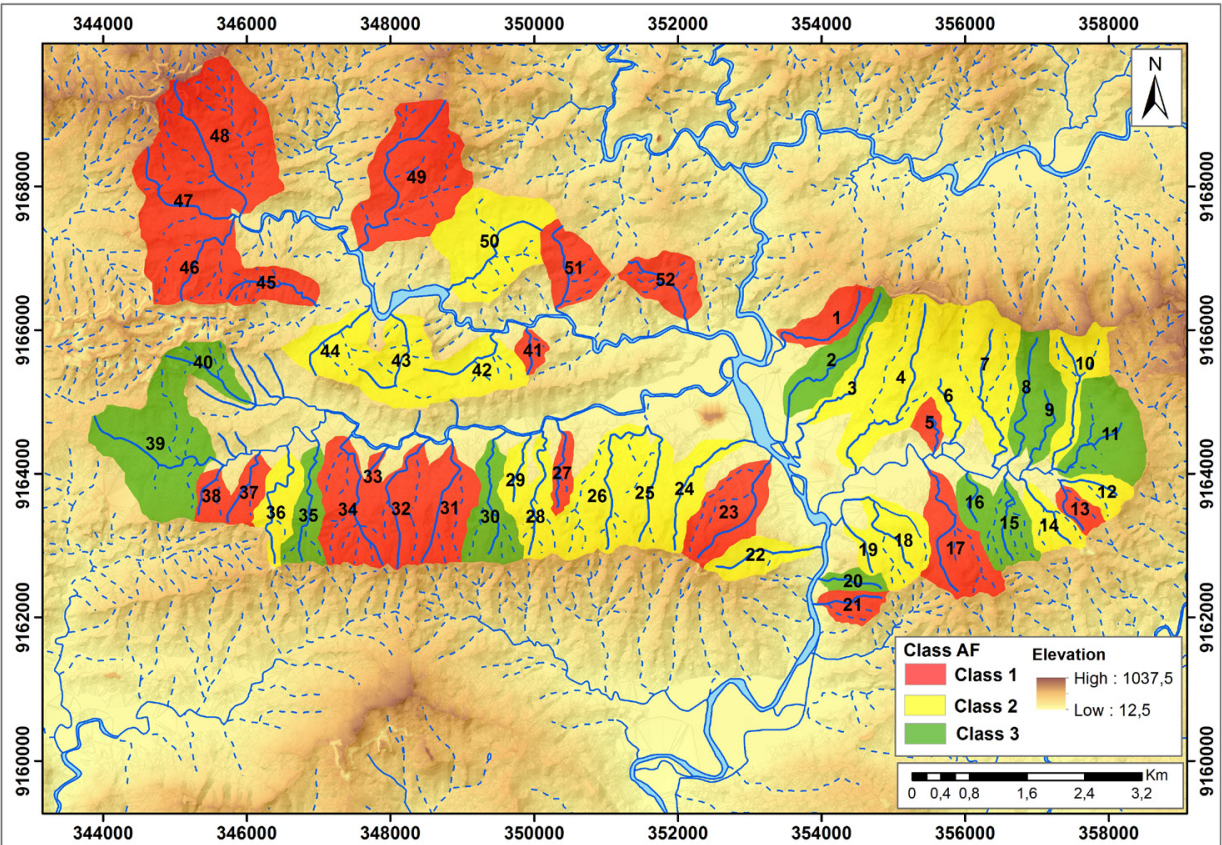

Figure 7: Classification of sub-watershed of the study area based on the measurement of the drainage basin asymmetry $(\mathrm{AF})$ indices

Table 3: Smf (mountain front sinuosity) values calculated in the 52 sub-watershed

\begin{tabular}{|l|l|l|l|l|}
\hline $\begin{array}{l}\text { No. Sub- } \\
\text { watershed }\end{array}$ & Lmf $(\mathbf{k m})$ & Ls $(\mathbf{k m})$ & Smf & Class \\
\hline 1 & 0.8999 & 0.4167 & 2.1598 & 3 \\
\hline 2 & 0.7999 & 0.3567 & 2.2428 & 3 \\
\hline 3 & 0.8899 & 0.5167 & 1.7224 & 3 \\
\hline 4 & 0.9899 & 0.6167 & 1.6053 & 3 \\
\hline 5 & 0.8700 & 0.5267 & 1.6519 & 3 \\
\hline 6 & 0.8989 & 0.5367 & 1.6751 & 3 \\
\hline 7 & 0.9799 & 0.6237 & 1.5712 & 3 \\
\hline 8 & 0.9889 & 0.6117 & 1.6168 & 3 \\
\hline 9 & 0.9799 & 0.6112 & 1.6034 & 3 \\
\hline 10 & 0.9999 & 0.6167 & 1.6215 & 3 \\
\hline 11 & 0.8505 & 0.6425 & 1.3239 & 2 \\
\hline 12 & 0.9879 & 0.6167 & 1.6020 & 3 \\
\hline 13 & 0.9778 & 0.6167 & 1.5856 & 3 \\
\hline 14 & 0.8915 & 0.4833 & 1.8448 & 3 \\
\hline 15 & 0.7004 & 0.5467 & 1.2811 & 2 \\
\hline 16 & 1.7413 & 0.9185 & 1.8958 & 3 \\
\hline 17 & 0.9032 & 0.4462 & 2.0240 & 3 \\
\hline 18 & 1.5787 & 0.7856 & 2.0094 & 3 \\
\hline 19 & 1.4627 & 0.7721 & 1.8945 & 3 \\
\hline 20 & 1.3404 & 0.3450 & 3.8847 & 3 \\
\hline 21 & 2.0186 & 0.7167 & 2.8166 & 3 \\
\hline 22 & 0.8427 & 0.2970 & 2.8374 & 3 \\
\hline 23 & 0.8907 & 0.3903 & 2.2820 & 3 \\
\hline 24 & 1.2841 & 0.4128 & 3.1109 & 3 \\
\hline 25 & 1.5008 & 0.5820 & 2.5786 & 3 \\
\hline 26 & 2.1758 & 0.6164 & 3.5298 & 3 \\
\hline 27 & 2.1919 & 0.6332 & 3.4618 & 3 \\
\hline & & & & \\
\hline
\end{tabular}

\begin{tabular}{|c|c|c|c|c|}
\hline $\begin{array}{l}\text { No. Sub- } \\
\text { watershed }\end{array}$ & Lmf (km) & Ls (km) & Smf & Class \\
\hline 28 & 1.5845 & 0.5474 & 2.8946 & 3 \\
\hline 29 & 2.4052 & 0.7222 & 3.3305 & 3 \\
\hline 30 & 1.6203 & 0.5850 & 2.7697 & 3 \\
\hline 31 & 1.6028 & 0.5337 & 3.0034 & 3 \\
\hline 32 & 0.8552 & 0.5371 & 1.5923 & 3 \\
\hline 33 & 1.3681 & 0.6859 & 1.9946 & 3 \\
\hline 34 & 0.6979 & 0.3449 & 2.0232 & 3 \\
\hline 35 & 2.3713 & 0.9834 & 2.4113 & 3 \\
\hline 36 & 1.7616 & 0.9455 & 1.8633 & 3 \\
\hline 37 & 0.9466 & 0.5515 & 1.7165 & 3 \\
\hline 38 & 1.4266 & 0.7203 & 1.9804 & 3 \\
\hline 39 & 0.9969 & 0.4320 & 2.3075 & 3 \\
\hline 40 & 1.3962 & 0.3132 & 4.4574 & 3 \\
\hline 41 & 2.0081 & 0.7161 & 2.8042 & 3 \\
\hline 42 & 0.8551 & 0.6162 & 1.3878 & 2 \\
\hline 42 & 0.8612 & 0.5609 & 1.5354 & 3 \\
\hline 43 & 0.9565 & 0.5583 & 1.7134 & 3 \\
\hline 44 & 0.9118 & 0.5752 & 1.5852 & 3 \\
\hline 45 & 0.8888 & 0.4515 & 1.9686 & 3 \\
\hline 46 & 1.7701 & 0.6634 & 2.6680 & 3 \\
\hline 47 & 2.5985 & 1.6517 & 1.5732 & 3 \\
\hline 48 & 1.2186 & 0.7936 & 1.5355 & 3 \\
\hline 49 & 2.1784 & 0.8854 & 2.4604 & 3 \\
\hline 50 & 1.6973 & 0.8517 & 1.9927 & 3 \\
\hline 51 & 1.6973 & 0.8217 & 2.0655 & 3 \\
\hline 52 & 1.6973 & 0.8317 & 2.0406 & 3 \\
\hline
\end{tabular}


Figure 8: Classification of sub-watershed of the study area based on the

measurement of the mountain front sinuosity (Smf) indices

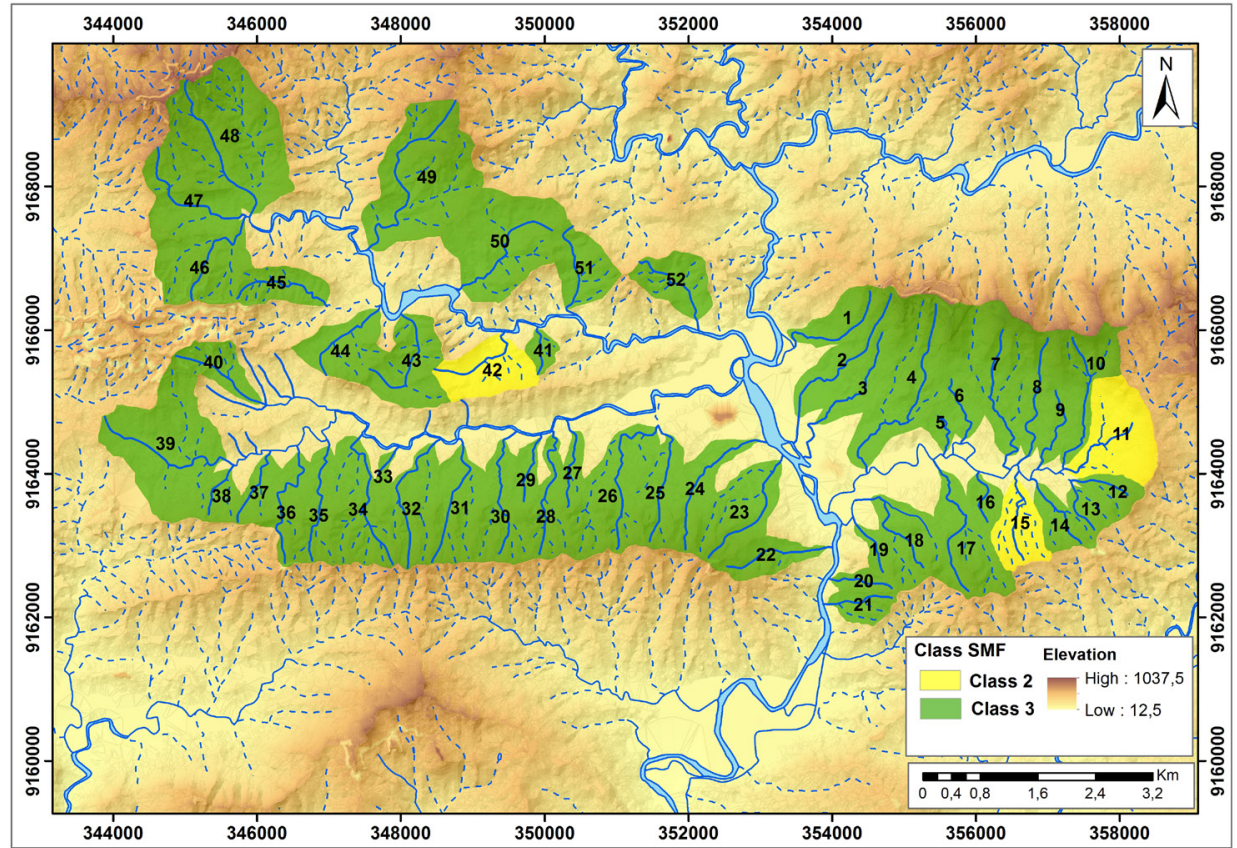

Table 4: BS (basin shape) values calculated in the 52 sub-watershed

\begin{tabular}{|c|c|c|c|c|}
\hline $\begin{array}{l}\text { No. Sub- } \\
\text {-watershed }\end{array}$ & Bl (km) & Bw (km) & BS & Class \\
\hline 1 & 1.443 & 0.500 & 2.89 & 3 \\
\hline 2 & 2.233 & 0.520 & 4.30 & 1 \\
\hline 3 & 1.608 & 0.457 & 3.52 & 2 \\
\hline 4 & 2.638 & 0.848 & 3.11 & 2 \\
\hline 5 & 0.796 & 0.435 & 1.83 & 3 \\
\hline 6 & 1.438 & 0.461 & 3.12 & 2 \\
\hline 7 & 2.181 & 0.771 & 2.83 & 3 \\
\hline 8 & 1.779 & 0.470 & 3.78 & 2 \\
\hline 9 & 1.385 & 0.493 & 2.81 & 3 \\
\hline 10 & 2.040 & 0.874 & 2.33 & 3 \\
\hline 11 & 1.328 & 1.632 & 0.81 & 3 \\
\hline 12 & 0.960 & 0.533 & 1.80 & 3 \\
\hline 13 & 0.767 & 0.387 & 1.98 & 3 \\
\hline 14 & 1.152 & 0.624 & 1.84 & 3 \\
\hline 15 & 1.199 & 0.745 & 1.61 & 3 \\
\hline 16 & 0.841 & 0.511 & 1.65 & 3 \\
\hline 17 & 2.014 & 0.969 & 2.08 & 3 \\
\hline 18 & 1.364 & 0.797 & 1.71 & 3 \\
\hline 19 & 0.842 & 0.352 & 2.39 & 3 \\
\hline 20 & 0.921 & 0.332 & 2.78 & 3 \\
\hline 21 & 0.986 & 0.501 & 1.97 & 3 \\
\hline 22 & 1.632 & 0.554 & 2.95 & 3 \\
\hline 23 & 1.781 & 0.883 & 2.02 & 3 \\
\hline 24 & 1.695 & 0.581 & 2.92 & 3 \\
\hline 25 & 1.603 & 0.618 & 2.59 & 3 \\
\hline 26 & 2.144 & 1.211 & 1.77 & 3 \\
\hline
\end{tabular}

\begin{tabular}{|c|c|c|c|c|}
\hline $\begin{array}{l}\text { No. Sub- } \\
\text {-watershed }\end{array}$ & BI (km) & Bw (km) & BS & Class \\
\hline 27 & 1.197 & 0.299 & 4.01 & 1 \\
\hline 28 & 1.692 & 0.587 & 2.89 & 3 \\
\hline 29 & 1.066 & 0.411 & 2.59 & 3 \\
\hline 30 & 1.705 & 0.848 & 2.01 & 3 \\
\hline 31 & 1.690 & 0.639 & 2.65 & 3 \\
\hline 32 & 1.776 & 0.728 & 2.44 & 3 \\
\hline 33 & 0.753 & 0.233 & 3.23 & 2 \\
\hline 34 & 1.821 & 0.686 & 2.65 & 3 \\
\hline 35 & 1.654 & 0.447 & 3.70 & 2 \\
\hline 36 & 1.620 & 0.551 & 2.94 & 3 \\
\hline 37 & 1.050 & 0.421 & 2.49 & 3 \\
\hline 38 & 0.753 & 0.486 & 1.55 & 3 \\
\hline 39 & 1.831 & 2.122 & 0.86 & 3 \\
\hline 40 & 0.391 & 0.189 & 2.08 & 3 \\
\hline 41 & 0.643 & 0.498 & 1.29 & 3 \\
\hline 42 & 1.202 & 0.774 & 1.55 & 3 \\
\hline 43 & 1.316 & 1.150 & 1.14 & 3 \\
\hline 44 & 1.196 & 0.890 & 1.34 & 2 \\
\hline 45 & 1.267 & 0.478 & 2.65 & 2 \\
\hline 46 & 1.585 & 1.411 & 1.12 & 3 \\
\hline 47 & 1.593 & 0.960 & 1.66 & 3 \\
\hline 48 & 2.215 & 1.491 & 1.49 & 3 \\
\hline 49 & 2.382 & 1.427 & 1.67 & 3 \\
\hline 50 & 1.782 & 1.457 & 1.22 & 3 \\
\hline 51 & 1.030 & 1.012 & 1.02 & 3 \\
\hline 52 & 0.984 & 1.086 & 0.91 & 3 \\
\hline
\end{tabular}

Rudarsko-geološko-naftni zbornik i autori (The Mining-Geology-Petroleum Engineering Bulletin and the authors) (C, 2021, pp. 85-105, DOI: $10.17794 /$ rgn.2021.4.8 


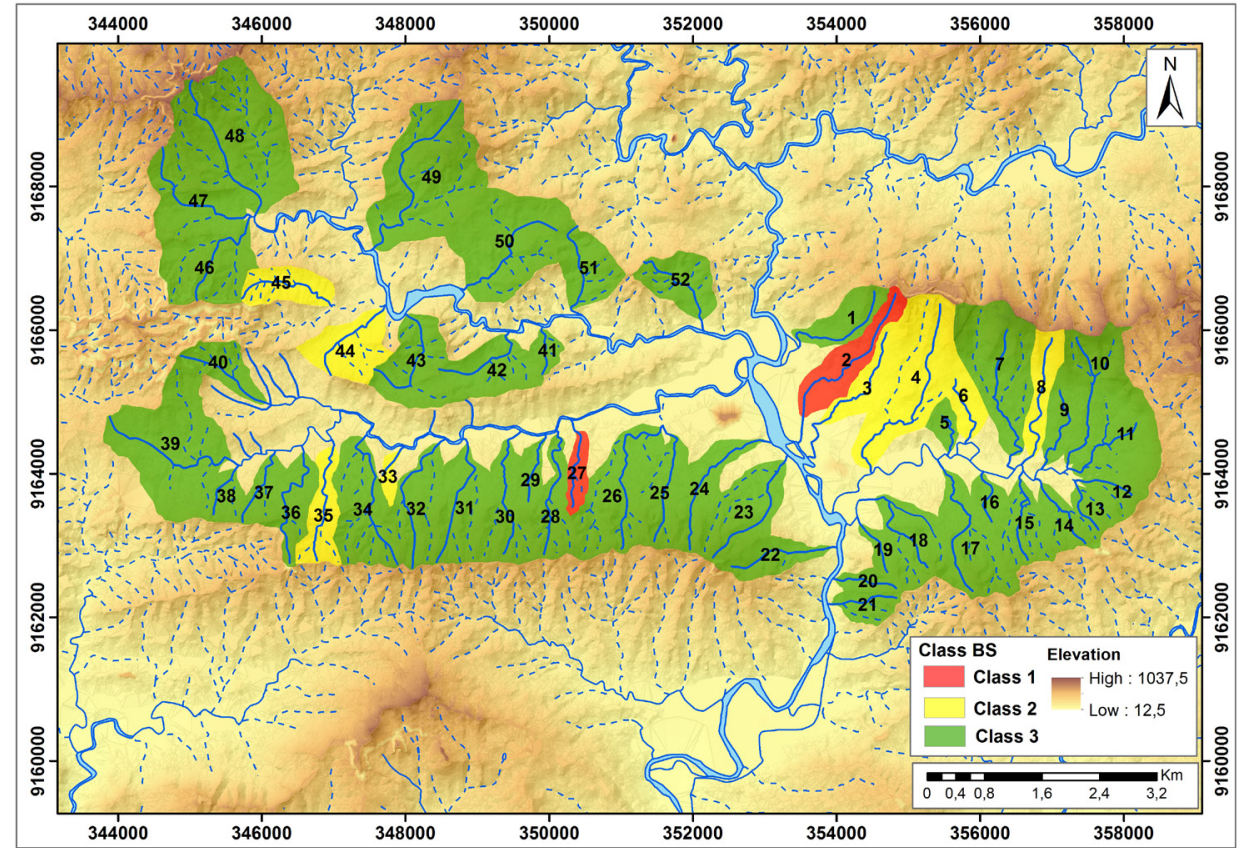

Figure 9: Classification of sub-watershed of the study area based on the measurement of the basin shape (BS) indices

Table 5: Dd (drainage density) values calculated in the 52 sub-watershed

\begin{tabular}{|c|c|c|c|c|}
\hline $\begin{array}{l}\text { No. } \\
\text { Sub- } \\
\text { watershed }\end{array}$ & $\begin{array}{l}\text { Total length } \\
\left(\sum \mathbf{L}\right)(\mathbf{k m})\end{array}$ & \begin{tabular}{|l} 
Area \\
watershed \\
$(\mathbf{A})\left(\mathbf{k m}^{2}\right)$
\end{tabular} & $\begin{array}{l}\text { Drainage } \\
\text { density } \\
\text { (Dd) }\end{array}$ & Class \\
\hline 1 & 1.754 & 0.566 & 3.096 & 2 \\
\hline 2 & 2.804 & 0.820 & 3.419 & 2 \\
\hline 3 & 2.551 & 0.539 & 4.738 & 2 \\
\hline 4 & 5.677 & 1.713 & 3.313 & 2 \\
\hline 5 & 0.690 & 0.207 & 3.337 & 2 \\
\hline 6 & 1.086 & 0.455 & 2.386 & 3 \\
\hline 7 & 5.587 & 1.590 & 3.513 & 2 \\
\hline 8 & 2.061 & 0.556 & 3.706 & 2 \\
\hline 9 & 1.377 & 0.490 & 2.811 & 2 \\
\hline 10 & 3.425 & 0.818 & 4.188 & 2 \\
\hline 11 & 2.762 & 1.238 & 2.231 & 3 \\
\hline 12 & 1.461 & 0.351 & 4.164 & 2 \\
\hline 13 & 1.511 & 0.248 & 6.093 & 1 \\
\hline 14 & 2.370 & 0.464 & 5.113 & 2 \\
\hline 15 & 4.587 & 0.652 & 7.040 & 1 \\
\hline 16 & 0.856 & 0.297 & 2.880 & 2 \\
\hline 17 & 4.232 & 1.096 & 3.862 & 2 \\
\hline 18 & 4.282 & 0.827 & 5.176 & 2 \\
\hline 19 & 0.924 & 0.194 & 4.756 & 2 \\
\hline 20 & 0.931 & 0.224 & 4.157 & 2 \\
\hline 21 & 2.004 & 0.345 & 5.818 & 1 \\
\hline 22 & 1.819 & 0.531 & 3.426 & 2 \\
\hline 23 & 4.503 & 1.055 & 4.268 & 2 \\
\hline 24 & 2.513 & 0.745 & 3.373 & 2 \\
\hline 25 & 2.931 & 0.717 & 4.086 & 2 \\
\hline 26 & 6.064 & 1.400 & 4.331 & 2 \\
\hline
\end{tabular}

\begin{tabular}{|c|c|c|c|c|}
\hline $\begin{array}{l}\text { No. } \\
\text { Sub- } \\
\text { watershed }\end{array}$ & $\begin{array}{l}\text { Total length } \\
\left(\sum \mathbf{L}\right)(\mathbf{k m})\end{array}$ & \begin{tabular}{|l|} 
Area \\
watershed \\
$(\mathrm{A})\left(\mathbf{k m}^{2}\right)$
\end{tabular} & $\begin{array}{l}\text { Drainage } \\
\text { density } \\
\text { (Dd) }\end{array}$ & Class \\
\hline 27 & 1.615 & 0.274 & 5.899 & 1 \\
\hline 28 & 3.533 & 0.654 & 5.406 & 2 \\
\hline 29 & 1.019 & 0.307 & 3.321 & 2 \\
\hline 30 & 3.623 & 0.829 & 4.368 & 2 \\
\hline 31 & 3.763 & 0.943 & 3.992 & 2 \\
\hline 32 & 4.305 & 0.907 & 4.748 & 2 \\
\hline 33 & 0.494 & 0.126 & 3.925 & 2 \\
\hline 34 & 6.218 & 1.190 & 5.224 & 2 \\
\hline 35 & 2.821 & 0.599 & 4.708 & 2 \\
\hline 36 & 2.460 & 0.612 & 4.017 & 2 \\
\hline 37 & 1.640 & 0.367 & 4.472 & 2 \\
\hline 38 & 1.367 & 0.288 & 4.741 & 2 \\
\hline 39 & 5.303 & 2.196 & 2.415 & 3 \\
\hline 40 & 0.421 & 0.061 & 6.912 & 1 \\
\hline 41 & 1.0523 & 0.1876 & 5.611 & 1 \\
\hline 42 & 2.8015 & 0.8582 & 3.264 & 2 \\
\hline 43 & 3.9421 & 0.9957 & 3.959 & 2 \\
\hline 44 & 2.8852 & 0.8146 & 3.542 & 2 \\
\hline 45 & 3.0937 & 0.5296 & 5.841 & 1 \\
\hline 46 & 4.3602 & 1.1465 & 3.803 & 2 \\
\hline 47 & 3.5248 & 1.1415 & 3.088 & 2 \\
\hline 48 & 9.6679 & 2.4804 & 3.898 & 2 \\
\hline 49 & 8.1068 & 2.2760 & 3.562 & 2 \\
\hline 50 & 13.5930 & 1.8009 & 7.548 & 1 \\
\hline 51 & 5.8553 & 0.7486 & 7.821 & 1 \\
\hline 52 & 3.0824 & 0.6992 & 4.409 & 2 \\
\hline
\end{tabular}


Figure 10: Classification of sub-watershed of the study area based on the measurement of the drainage density (Dd) indices

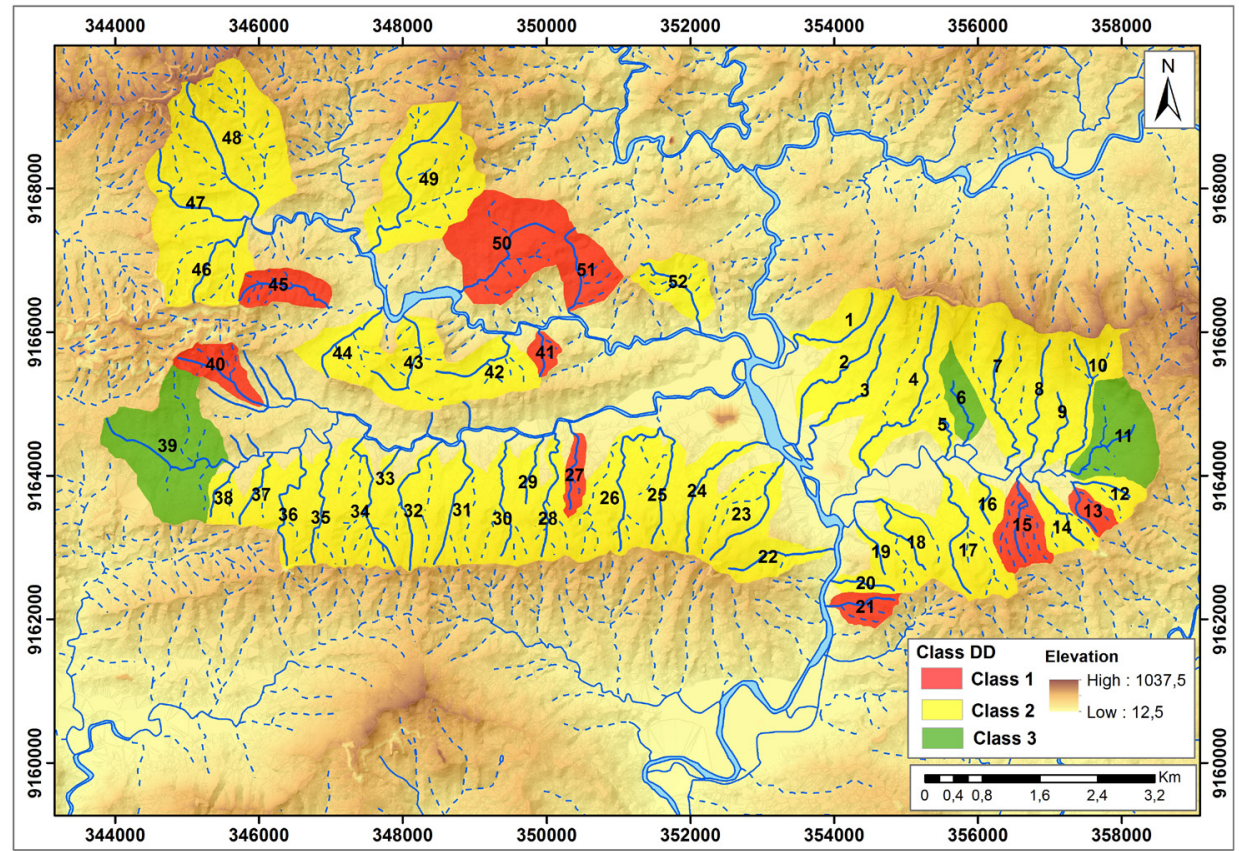

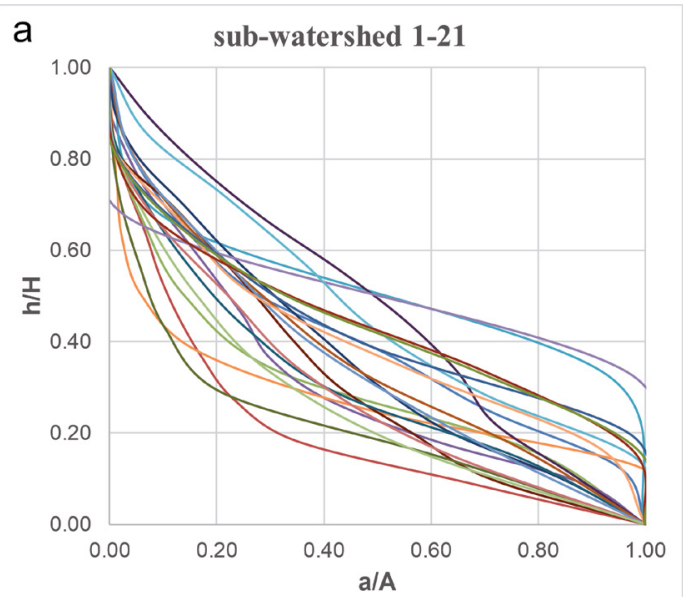

$-1-2-3-4-5-6-7-8-9-10-11$

$-12-13-14-15-16-17-18-19-20-21$

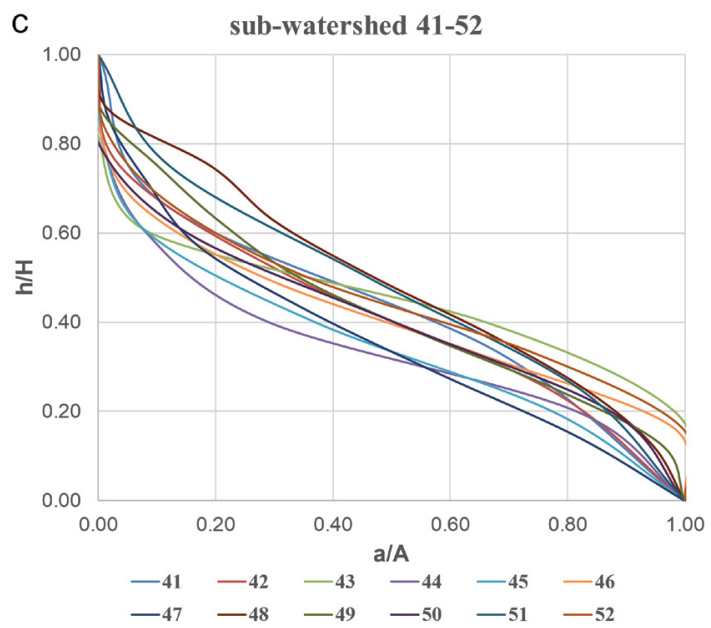

b

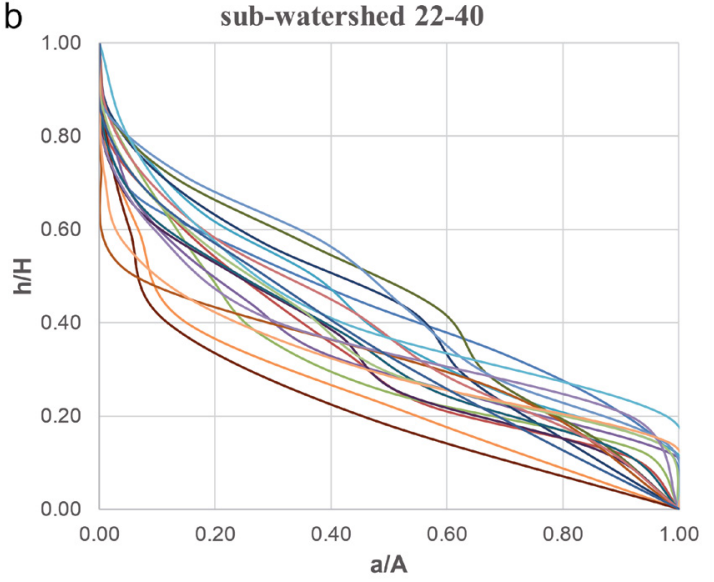

$-22-23-24-25-26-27-28-29-30-31$

Figure 11: a.b.c. The graph of the hypsometric curve in the study area ( 52 sub-watersheds) is dominant in a curve resembling the letter $S$ and a concave curve, showing that the sub-watershed is moderately eroded. Hypsometry curves of sub-watershed from the left margin of the study area. (A) is the total surface of the sub-watershed, (a) is the surface area within the sub-watershed above a given line of elevation (h), $(\mathrm{H})$ is the highest elevation of the sub-watershed. 


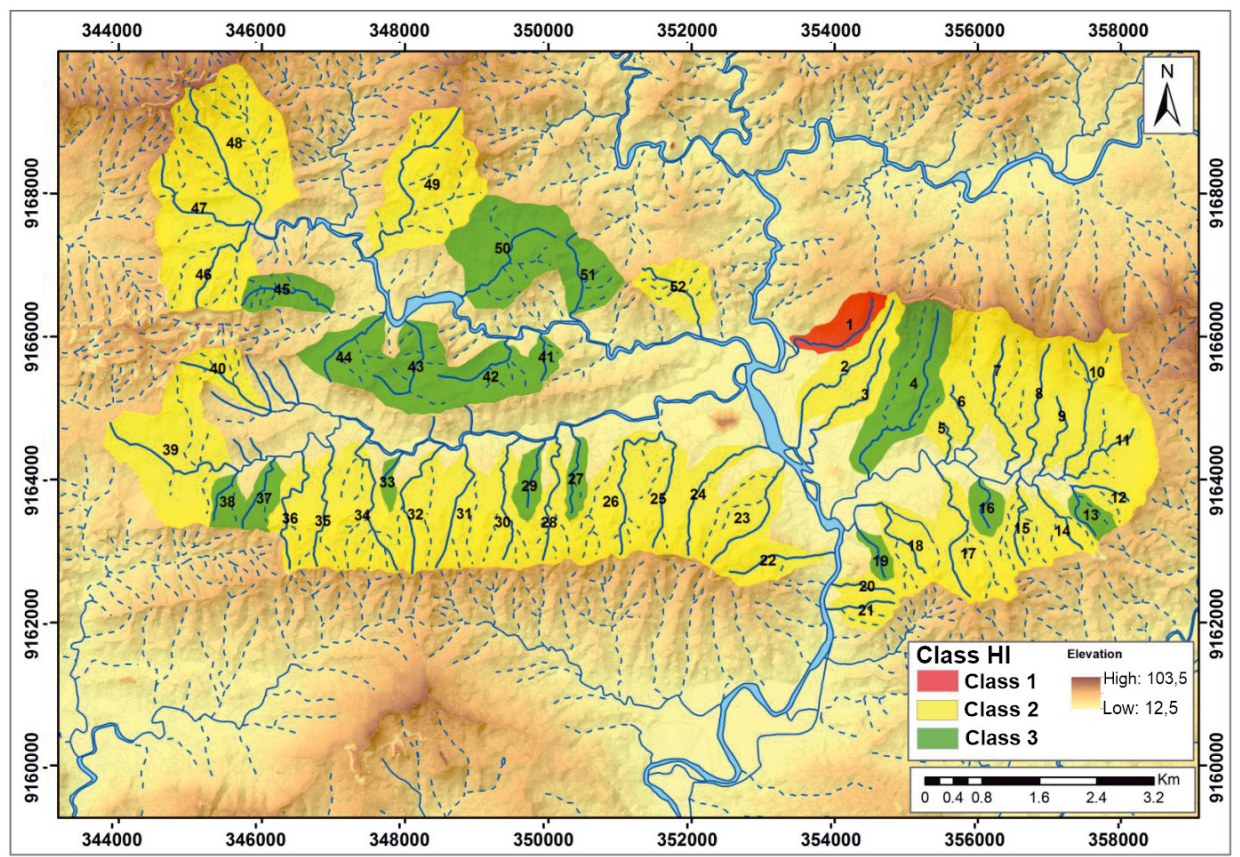

Figure 12: Classification of sub-watershed of the study area based on the measurement of the hypsometry integral (HI) indices

5.519) in class 2 , and grade 5 is fine (5.520-6.899) to grade 6 is very fine (6.9-8.279) in class 1 . The value of Dd in the research area starts from 2.231 to 7.040 , with the dominant value being in class 2 (see Table 5 and Figure 10).

\subsubsection{Curves and Hypsometric Integral (HC and $\mathrm{HI}$ )}

The HC and HI values are obtained from the calculation of each sub-watershed. The curve shape and HI value are controlled by geological factors, especially rock and geological structures (Flavio, 2015). The HI values are grouped into three classes for the convexity or concavity of the hypsometric curve: class 1 with a convex hypsometric curve (HI>0.5), class 2 with a concave-convex hypsometric curve (0.4-0.5), and class 3 with a concave hypsometric curve $(\mathrm{HI}<0.4)$ as shown in Figure 11 and Figure 12.

\subsubsection{Relative Tectonic Activity Index (IAT)}

This study uses seven geomorphic index parameters to produce a relative index of tectonic activity (IAT). IAT is obtained from the different class averages of each geomorphic index $(S / n)$ parameter. $S$ is the sum of the tectonic active class values divided by the number of geomorphic index parameters $(n)$. The value of IAT is grouped into 4 classes to determine the level of active tectonic relativity, as follows: class 1: very high (1.0 1.5); class 2: high (1.5 - 2); class 3: moderate $(2-2.5)$; and class 4: low (2.5 - 3) (El-Hamdouni et al., 2008) (see Table 6).
In this study, the IAT scores were only divided into 3 classes, because none of the IAT scores were in the very high category. The calculation of seven geomorphic index parameters in 52 sub-watersheds has resulted in IAT values with a percentage of class 1 of $0 \%$ (very high), class 2 of $11 \%$ (high-red), class 3 of $54 \%$ (moderateyellow); and grade 4 at 35\% (low-green) (see Figure 13). This value indicates that most of the research area is in class 3 , meaning that tectonic activity is in the moderate class. The class of medium or moderate tectonic activity indicates that the tectonic processes are balanced by the erosion process. Based on geological data, the IAT 3 value in the study area is composed of volcanic breccia rocks of the Waturanda Formation, which are scattered in the limb of the Karangsambung anticline (see Figure 13). Values IAT in class 2 are scattered in several sub-watersheds were prepared by igneous block and metamorphic parts of Luk Ulo mélange complex (see Figure 13). These rock blocks are embedded in the Luk Ulo melange claystone matrix. Differences in rock hardness between blocks and melange matrix affect their resistance, thus causing different levels of erosion.

\subsection{The geological field evidence}

Geological data, such as rock types and geological structures, are an important part of this research. Rock resistance and geological structure affect morphology, and this concerns the level of weathering and erosion. In the study area, in addition to rock types and geological structures, river terrace deposits were found which were composed of layers of cobble, gravel, sand, and soil above it. The cobble layer consists of andesite due to 
Table 6: Classification of tectonic activity levels (IAT) based on the calculation of the geomorphic index parameter (Smf/Mountain front sinuosity, Vf/valley floor width-valley height ratio, SL/stream-gradient index, AF/drainage basin asymmetry, BS/drainage basis shape, Dd/drainage density, HI/Hipsometry integral).

\begin{tabular}{|c|c|c|c|c|c|c|c|c|c|c|}
\hline No. sub-watershed & Smf & $V \mathbf{f}$ & SL & $\mathbf{A F}$ & BS & Dd & HI & $\mathbf{S} / \mathbf{n}$ & IAT & Tectonic activity \\
\hline 1 & 3 & 3 & 2 & 1 & 3 & 2 & 1 & 2.14 & 3 & Moderately active \\
\hline 2 & 3 & 3 & 1 & 3 & 1 & 2 & 2 & 2.14 & 3 & Moderately active \\
\hline 3 & 3 & 3 & 3 & 2 & 2 & 2 & 2 & 2.43 & 3 & Moderately active \\
\hline 4 & 3 & 3 & 1 & 2 & 2 & 2 & 3 & 2.29 & 3 & Moderately active \\
\hline 5 & 3 & 3 & 3 & 1 & 3 & 2 & 2 & 2.43 & 3 & Moderately active \\
\hline 6 & 3 & 3 & 3 & 2 & 2 & 3 & 2 & 2.57 & 4 & Low active \\
\hline 7 & 3 & 3 & 1 & 2 & 3 & 2 & 2 & 2.29 & 3 & Moderately active \\
\hline 8 & 3 & 3 & 1 & 3 & 2 & 2 & 2 & 2.29 & 3 & Moderately active \\
\hline 9 & 3 & 3 & 3 & 3 & 3 & 2 & 2 & 2.71 & 4 & Low active \\
\hline 10 & 3 & 3 & 1 & 2 & 3 & 2 & 2 & 2.29 & 3 & Moderately active \\
\hline 11 & 2 & 3 & 3 & 3 & 3 & 3 & 2 & 2.71 & 4 & Low active \\
\hline 12 & 3 & 3 & 3 & 2 & 3 & 2 & 2 & 2.57 & 4 & Low active \\
\hline 13 & 3 & 3 & 3 & 1 & 3 & 1 & 3 & 2.43 & 3 & Moderately active \\
\hline 14 & 3 & 3 & 3 & 2 & 3 & 2 & 2 & 2.57 & 4 & Low active \\
\hline 15 & 2 & 3 & 3 & 3 & 3 & 1 & 2 & 2.43 & 3 & Moderately active \\
\hline 16 & 3 & 3 & 3 & 3 & 3 & 2 & 3 & 2.86 & 4 & Low active \\
\hline 17 & 3 & 3 & 2 & 1 & 3 & 2 & 2 & 2.29 & 3 & Moderately active \\
\hline 18 & 3 & 3 & 2 & 2 & 3 & 2 & 2 & 2.43 & 3 & Moderately active \\
\hline 19 & 3 & 2 & 3 & 2 & 3 & 2 & 3 & 2.57 & 4 & Low active \\
\hline 20 & 3 & 2 & 3 & 3 & 3 & 2 & 2 & 2.57 & 4 & Low active \\
\hline 21 & 3 & 2 & 3 & 1 & 3 & 1 & 2 & 2.14 & 3 & Moderately active \\
\hline 22 & 3 & 2 & 2 & 3 & 3 & 2 & 2 & 2.43 & 3 & Moderately active \\
\hline 23 & 3 & 2 & 2 & 1 & 3 & 2 & 2 & 2.14 & 3 & Moderately active \\
\hline 24 & 3 & 3 & 1 & 3 & 3 & 2 & 2 & 2.43 & 3 & Moderately active \\
\hline 25 & 3 & 3 & 1 & 3 & 3 & 2 & 2 & 2.43 & 3 & Moderately active \\
\hline 26 & 3 & 3 & 2 & 3 & 3 & 2 & 2 & 2.57 & 4 & Low active \\
\hline 27 & 3 & 3 & 2 & 1 & 1 & 1 & 3 & 2.00 & 2 & Highly active \\
\hline 28 & 3 & 2 & 2 & 3 & 3 & 2 & 2 & 2.43 & 3 & Moderately active \\
\hline 29 & 3 & 3 & 3 & 3 & 3 & 2 & 3 & 2.86 & 4 & Low active \\
\hline 30 & 3 & 2 & 2 & 3 & 3 & 2 & 2 & 2.43 & 3 & Moderately active \\
\hline 31 & 3 & 1 & 2 & 1 & 3 & 2 & 2 & 2.00 & 2 & Highly active \\
\hline 32 & 3 & 1 & 2 & 1 & 3 & 2 & 2 & 2.00 & 2 & Highly active \\
\hline 33 & 3 & 3 & 3 & 1 & 2 & 2 & 3 & 2.43 & 3 & Moderately active \\
\hline 34 & 3 & 1 & 1 & 1 & 3 & 2 & 2 & 1.86 & 2 & Highly active \\
\hline 35 & 3 & 1 & 3 & 3 & 2 & 2 & 2 & 2.29 & 3 & Moderately active \\
\hline 36 & 3 & 3 & 2 & 2 & 3 & 2 & 2 & 2.43 & 3 & Moderately active \\
\hline 37 & 3 & 3 & 2 & 1 & 3 & 2 & 3 & 2.43 & 3 & Moderately active \\
\hline 38 & 3 & 3 & 3 & 1 & 3 & 2 & 3 & 2.57 & 4 & Low active \\
\hline 39 & 3 & 1 & 3 & 3 & 3 & 3 & 2 & 2.57 & 4 & Low active \\
\hline 40 & 3 & 2 & 1 & 3 & 3 & 1 & 2 & 2.14 & 3 & Moderately active \\
\hline 41 & 3 & 3 & 3 & 1 & 3 & 3 & 3 & 2.71 & 4 & Low active \\
\hline 42 & 2 & 3 & 2 & 2 & 3 & 2 & 3 & 2.43 & 3 & Moderately active \\
\hline 43 & 3 & 1 & 3 & 2 & 3 & 2 & 3 & 2.43 & 3 & Moderately active \\
\hline 44 & 3 & 3 & 2 & 2 & 2 & 2 & 3 & 2.43 & 3 & Moderately active \\
\hline 45 & 3 & 3 & 2 & 1 & 2 & 1 & 3 & 2.14 & 3 & Moderately active \\
\hline 46 & 3 & 2 & 2 & 1 & 3 & 2 & 2 & 2.14 & 3 & Moderately active \\
\hline 47 & 3 & 1 & 2 & 1 & 3 & 2 & 2 & 2.00 & 2 & Highly active \\
\hline 48 & 3 & 1 & 1 & 1 & 3 & 2 & 2 & 1.86 & 2 & Highly active \\
\hline 49 & 3 & 1 & 2 & 1 & 3 & 2 & 2 & 2.00 & 2 & Highly active \\
\hline 50 & 3 & 3 & 3 & 2 & 3 & 3 & 3 & 2.86 & 4 & Low active \\
\hline 51 & 3 & 2 & 3 & 1 & 3 & 3 & 3 & 2.57 & 4 & Low active \\
\hline 52 & 3 & 1 & 3 & 1 & 3 & 2 & 2 & 2.14 & 3 & Moderately active \\
\hline
\end{tabular}




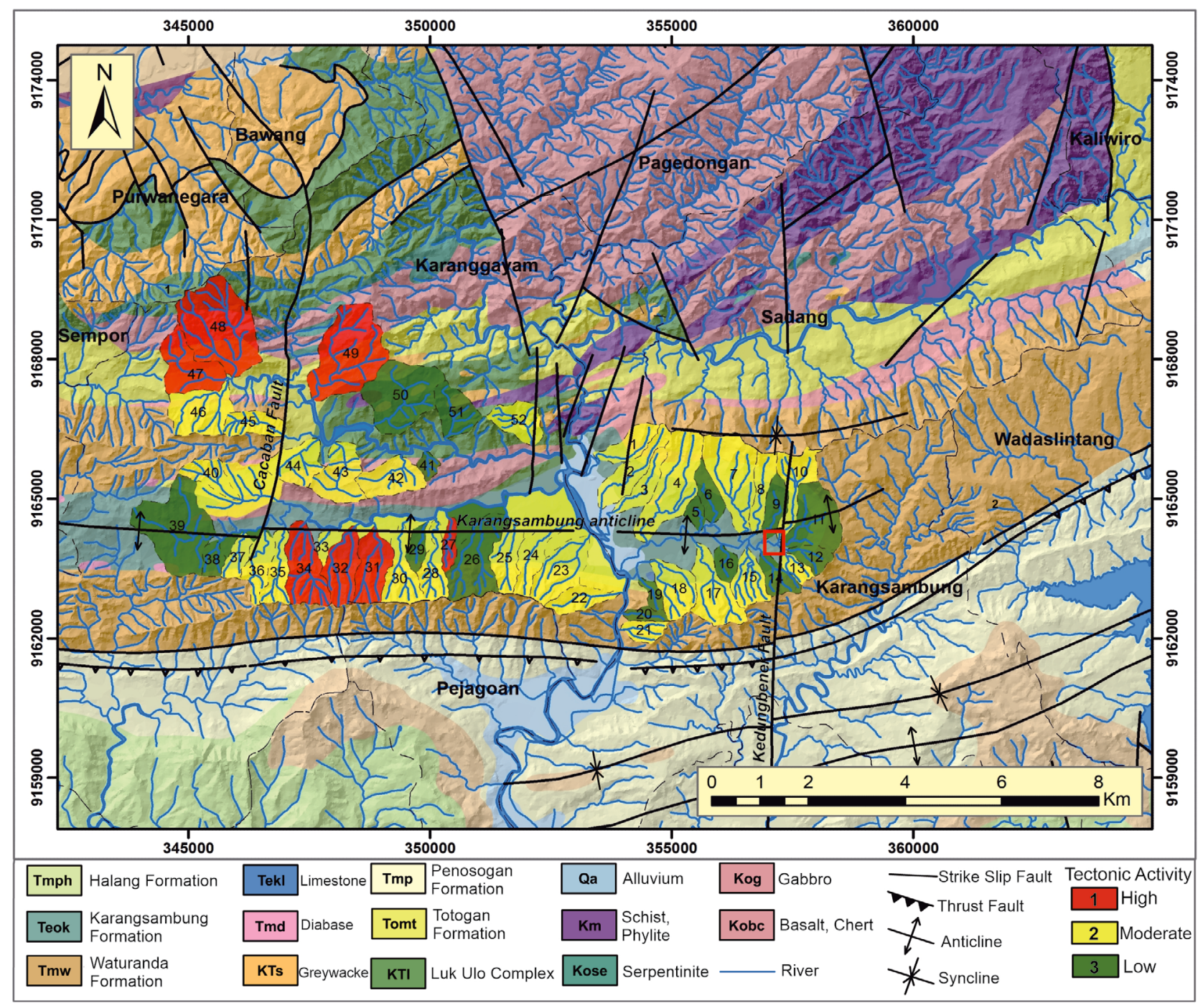

Figure 13: Overlap map of the index of tectonic activity (IAT) and geological map. The river terrace outcrop location (Red Box)

erosion from the volcanic breccia of the Waturanda Formation. The cobble shape is sub-rounded to angular. The cobble layer is inserted with basalt gravel and andesite, which is covered by sand. T-1 comprises of a layer of cobble and gravel that is not very clear because it is covered by sand and organic soil. It is about 10 meters high from the riverbed (see Figure 14). Elsewhere, river terrace outcrops are showing discontinuous cobble and gravel layers, intersected by joints (see Figure 15).

\section{Discussion}

Research has produced active tectonic information in a wide area using several geomorphological indices. Many previous studies have used geomorphic index calculations to evaluate the relativity of active tectonics, especially those associated with active faults (Bull and McFadden, 1977; Rockwell et al., 1985; Azor et al., 2002; Silva et al., 2003; Keller and Pinter, 1996). Many approaches use a combination of two or more parameters of a geo- morphic index to provide semi-quantitative information for assessing active tectonic relativity (Bull and McFadden, 1977; Silva et al,. 2003; El-Hamdouni et al., 2008; Keller and Pinter, 1986, 1996, 2002).

In the study area, geomorphic indices are used to determine tectonic activity, especially those related to uplift and indications of active faults. The shape of the subwatershed, the shape of the river flow pattern, the shape of the steep river valley, and the steep hills indicate uplifting in the study area. Geological structure and rock resistance can reflect the level of tectonic activity in the study area. Evidence of faults, folds, and intensive joint distribution are indications that the area is heavily influenced by tectonic activity. Rock hardness can determine the active tectonic indication of the study area because rock resistance affects topographic relief. Topographic relief affects the result of the geomorphic index calculation in the study area. The calculation of the geomorphic index parameters will focus on the Karangsambung amphitheater landscape, which is the core part of the study 


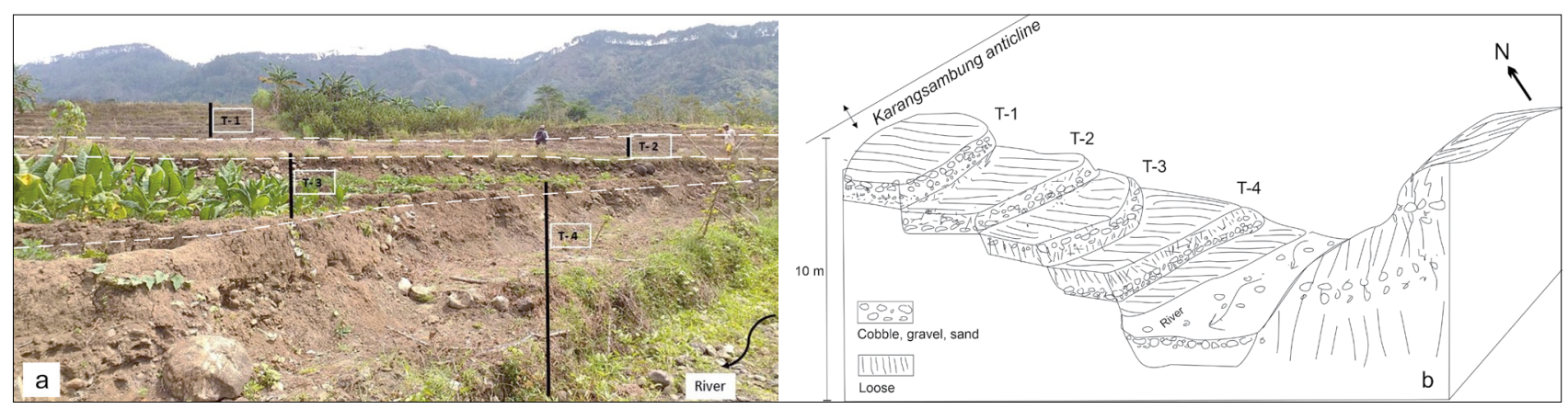

Figure 14: a) River terraces, the oldest terraces ( $\left.\mathrm{T}_{1}\right)$ are higher standing than the younger terraces ( $\mathrm{T}_{2}$ and $\left.\mathrm{T}_{3}\right)$ and the present floodplain $\left.\left(\mathrm{T}_{4}\right), \mathbf{b}\right)$ Geomorphological schematic of fluvial terraces along the Welaran River in the eastern part of the study area

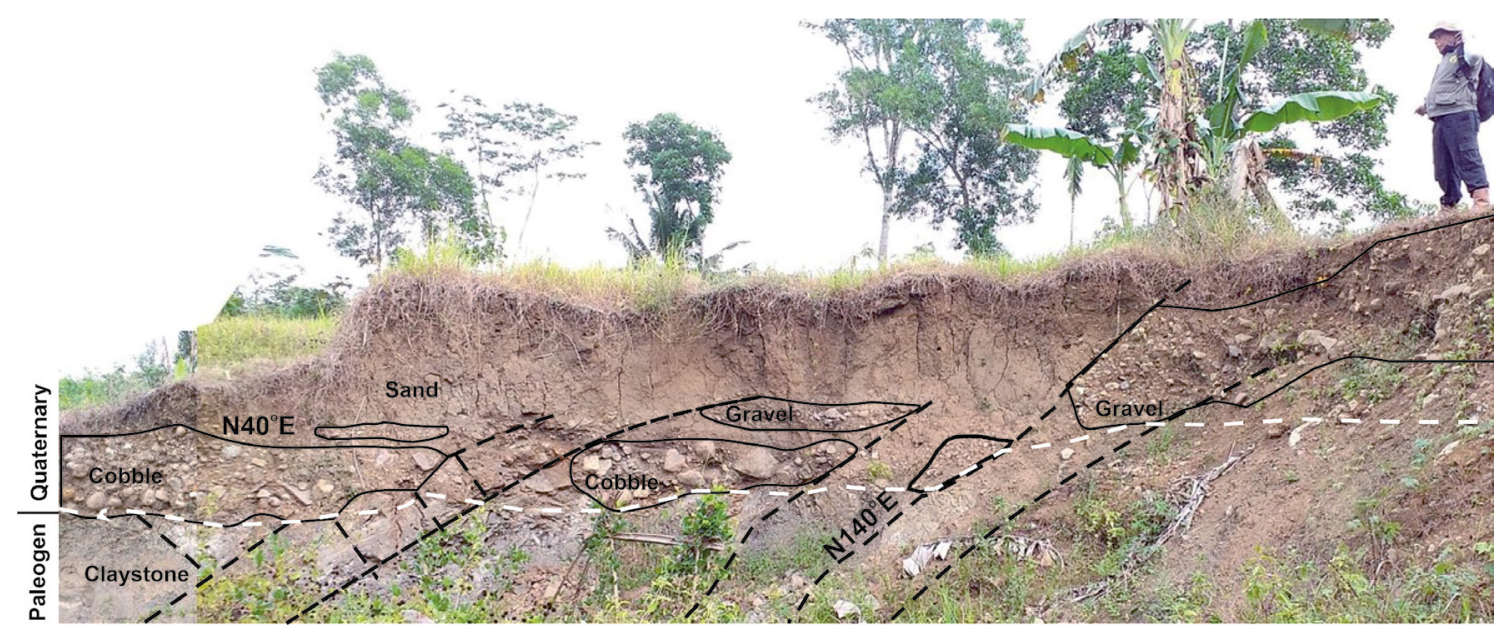

Figure 15: Outcrop of river terrace above the claystone bedrock of the Karangsambung Formation.

area. Based on geological data, the landscape of the Karangsambung amphitheater is an anticline valley that extends in the east-west direction and reveals Paleogene rocks (Asikin, 1974; Harsolumakso, 1996). In the deep valley morphology, several solitary hills are formed by olistolite blocks such as greywacke, limestone, and lava embedded in the claystone matrix of the Karangsambung Formation (Asikin, 1974; Harsolumakso, 1996; Prasetyadi 2006; Handayani et al., 2021) (Figure 1b and Figure 1c). The resistance of the rock blocks produces a steep hillside morphology with steep slopes. The morphology is also influenced by the formation that causes vertical erosion that forms the Karangsambung amphitheater valley. In addition, the exposure of Cretaceous rocks in the study area results from the uplifting process's mechanism due to the confluence of two large faults, namely the Muria-Kebumen Fault and the PamanukanCilacap Fault (Satyana, 2002) (see Figure 2). In addition, based on gravity data, it shows that the research area is the part that is experiencing uplift (Subagio, 2008).

The geomorphic index analysis shows that the Vf value reflects the different slopes in each valley forming a steep slope with a V-shaped valley. The results of the calculation of the $\mathrm{Vf}$ geomorphic index show a value of 0.25 to 12.75 . The $\mathrm{V}$-shaped valley has a relatively low
Vf value, and the U-shaped valley has a high Vf value. High Vf values dominate the eastern part of the study area, from sub-watersheds 1 to 20 . Classes 1 and 2 are spread over the northern and southern parts of the study area. The high value of Vf in the eastern part of the study area is strongly influenced by andesite breccia lithology. Meanwhile, the V-shaped valley has a low Vf value, controlled by lithology and geological structures in the form of faults and joints. The lithology is composed of claystone and igneous rock as olistolite blocks in the Karangsambung Formation (see Figure 5 and Figure 13).

The average Af value is in classes 2 and 3, reflecting the shape of the steep and asymmetrical valley due to the influence of tectonic activity, which results in the slope of the sub-watershed so that there is an elevation difference. The index is sensitive to change in inclination perpendicular to the channel direction. An Af factor above or below 50 may result from basin tilting, either as a result of active tectonics or lithologic structural control differential erosion, for example, the stream slipping down bedding plains over time (El-Hamdouni et al. 2008) (see Figure 7 and Figure 13).

The BS value of the research area is dominated by class 3 , meaning that tectonic activity is low. The low value of the tectonic activity is reflected in the shape of 
the sub-watershed, which tends to be more circular. The shape of the circular sub-watershed indicates a balanced erosion process between lateral and vertical directions (Ramírez-Herrera, 1998) (see Figure 9).

Streams-gradients index (SL) was high, and the integral curve hypsometry also showed a larger tectonic influence than the erosion process. Development of topography results from an adjustment between erosion processes as streams and rivers flow over rocks and soils of variable strength (Hack, 1973). These HI and SL values reflect the relief of each sub-watershed landscape surface, which tends to be rough and forms a fairly large height difference between the peak and the bottom of each sub-watershed. Geological structures in the form of faults and joints and rock resistance greatly affect the SL value. The high SL value in the study area indicates a steep topography with lithology in the form of resistant volcanic breccias. The HI value of the study area is dominated by class 3 or moderate tectonic activity. The HI value reflects the rough topographic relief due to the influence of rock resistance composed by the Waturanda Formation breccia, which is relatively hard and joints developed intensively (see Figure 12 and Figure 13).

The results of the IAT analysis show that the research area is dominated by the moderately tectonic class 3 (moderate). However, in the western part of the study area, several sub-watersheds fall into the category of high tectonic activity (class 2). In terms of rock types and geological structures, the western part is comprised of mélange rock blocks such as gabbro, schist, greywacke, chert, and lava, while the eastern part is composed of breccia and claystone. In addition, the western part of the study area is affected by intensive faults (Cacaban Fault) and jointing (see Figure 13). In contrast, the eastern part is only affected by faults and is slightly jointed. Different types of constituent rocks and geological structures that develop produce other morphological formations. In the western part of the study area, the morphology formed is in sharp hills with steep slopes and narrow valleys. This affects the slope and the shape of the formed valley. The valley formed is reflected by steep slopes and narrow valley bottoms resembling the letter $\mathrm{V}$. The shape of the $\mathrm{V}$ valley is influenced by the uplift process, so that vertical erosion is more dominant than lateral erosion.

Field geological evidence shows neotectonic activity in the form of uplift and indications of an active fault. This is shown by the evidence of the deformation of the uplifted river terrace. The river terrace deposits (T-1 to T-4) are composed of a layer of cobble, gravel, sand, and overlying soil (see Figure 14). River terraces and floodplains indicate channel-sediment dynamics and represent important landform features, which can be used to untangle the evolutionary history of climate and tectonic conditions in a certain area (Trenc et al., 2019). Regional tectonic strength significantly impacts river terraces' formation, similar to the Manas River in China (Zhijun
Gong, 2014). In other locations, indications of tectonic deformation are in the form of terrace outcrops showing discontinuity of the layer planes (see Figure 15). The deformation mechanism is indicated by the relative movement associated with the fault zone in the form of shear zones and fracture zones that are well preserved in the rock. These fractures generally indicate stress-controlled tectonic deformation. Deformation on the terrace is the youngest tectonic influence, estimated by the dextral strike-slip movement of the Kedungbener Fault activity (see Figure 13). Seismic historical records show that this fault had shifted in 1852 on a 6-7 MMI scale (URL 3). This evidence indicates the presence of neotectonic activity that affects the geological and geomorphological conditions of the study area.

Active tectonic indications of the study area are influenced by north-south trending compression stress due to subduction activity in southern Java, which is known as the Sunda megathrust active zone south of Java (Saputra et al., 2020) (see Figure 1a). This compression stress has the potential to reactivate the faults in the study area to become active faults. Several epicenters were recorded around the study area with depths ranging from $10 \mathrm{~km}$ to $70 \mathrm{~km}$ and very few hypocenters with shallow depths $(<30 \mathrm{~km})$ (URL 2). Thus, the possibility of an earthquake is still related to the subduction process in the south of the study area. Seismicity history showed the incidence of earthquakes affecting research in 1852, 1863, and 1871 with a MMI scale of VII (URL 3). Seismic recordings also show two earthquake epicenters, namely 1) depth of $10 \mathrm{~km}$, M3.7; 2) depth 33 km, M4.7 (URL 2). Laterally, the epicenter of the two earthquakes was about $30 \mathrm{~km}$ from the study area. Thus, the seismic data indicate an earthquake source originating from an active fault shift that can affect the tectonic activity of the study area.

\section{Conclusions}

The tectonic geomorphic index is a tool to analyze the influence of active tectonic in a large area using GIS, which is based on the value of the ratio of valley floor width to valley height (Vf), drainage basin asymmetry (AF), stream length - gradient index (SL), the basin shape index (BS), mountain front sinuosity (Smf), drainage density (Dd), and the correlated hypsometric integral/hypsometric curve (HI / HC) obtained active tectonic index (IAT) values, namely high tectonic activity $(13 \%)$, moderate tectonic activity $(56 \%)$, and low tectonic activity $(31 \%)$. The results of the IAT show that the tectonic activity of the study area is dominated by the moderate class, meaning that the influence of tectonic activity is balanced with erosional activity in shaping the morphology of the study area. Although in some subwatersheds, it shows that tectonic activity is more influential than erosion. The high IAT value is in the northwest of the study area, which has a morphology with steep hills, narrow river valleys, is composed of resistant 
rocks and is crossed by a fault zone. The analysis of the geomorphic index and geological data indicates that the study area is influenced by the uplift process and has indications of neotectonic activity.

\section{Acknowledgment}

The authors express their appreciation and gratitude to the Deputy for Earth Sciences of the Indonesian Institute of Sciences, the Head of the Research Center for Geotechnology, and the supervisors and other parties for their support in this research. I would like to thank Priyo Hartanto for his suggestions for this paper.

\section{References}

Arrowsmith, J. R., and Zielke, O. (2009): Tectonic geomorphology of the San Andreas Fault zone from high resolution topography: An example from the Cholame segment. Geomorphology, 113, 1-2, 70-81. https://doi.org/10.1016 /j.geomorph.2009.01.002.

Asikin S. (1974): Geological Evolution of Central Java and Its Surroundings in terms of the New World Tectonic Theory, Doctoral Dissertation, Bandung Institute of Technology, unpublished, 103 p. (in Indonesian).

Asikin S., Handoyo A., Busono H., and Gafoer S. (1992): Geologic Map of Kebumen Quadrangle, Java, scale 1 : 100.000. Geological Research and Development Center, Bandung. (in Indonesian).

Azor, A., Keller, E. A., Yeats, R. S. (2002): Geomorphic Indicators of Active Fold Growth: South Mountain-Oak Ridge Anticline, Ventura Basin, Southern California. Geological Society of America Bulletin, 114, 6, 745-753. https://doi. org/10.1130/0016-7606(2002)1142.0.co;2.

Bull, W., McFadden, L. (1977): Tectonic Geomorphology North and South of the Garlock Fault, California. in: Proceedings Vol. of 8th Annual Geomorph. Symp. (Edited by Doering, D.O.) State University of New York at Binghamton, Binghamton, NY., pp. 116-138.

Burbank, D. W. and Anderson, R. S. (2001): Tectonic geomorphology. Blackweel Publishing, ISBN 978-0-632-04386-6.

Cannon, P.J. (1976): Generation of explicit parameters for a quantitative geomorphic study of Mill Creek drainage basin. Oklahoma Geology Notes, 36, 1, 3-16.

Clements, B., Hall, R., Smyth, H. R., Cottam, M. A. (2009): Thrusting of a volcanic arc: A new structural model for Java. Petroleum Geoscience, 15, 2, 159-174. https://doi. org/10.1144/1354-079309-831.

Condon, W.H., Pardyanto, L., Ketner, K.B., Amin, T.C, Gafoer, S., and Samodra, H. (1996): Geological maps of Banjarnegara and Pekalongan sheets, Java, Geol. Res. And the Development Center (P3G), Bandung.

El Hamdouni, R., Irigaray, C., Fernández, T., Chacón, J., Keller, E. A. (2008): Assessment of relative active tectonics, southwest border of the Sierra Nevada (southern Spain). Geomorphology, 96, 1-2, 150-173. https://doi.org/10.1016 /j.geomorph.2007.08.004.

Faghih, A., Esmaeilzadeh Soudejani, A., Nourbakhsh, A., Rokni, S. (2015): Tectonic geomorphology of High Zagros
Ranges, SW Iran: an initiative towards seismic hazard assessment. Environmental Earth Sciences, 74, 4, 30073017. https://doi.org/10.1007/s12665-015-4331-9.

Flavio Giaconia, Guillermo Booth-Rea, José Miguel Martínez-Martínez, José Miguel Azañón, José Vicente PérezPeña, Joaquín Pérez-Romero, Irene Villegas. (2012): Geomorphic evidence of active tectonics in the Sierra Alhamilla (eastern Betics, SE Spain), Geomorphology, 145,146, 90-106. https://doi.org/10.1016/j.geomorph.2011.12.043.

Galadini F, Galli P. (2000): Active tectonics in the central Apennines (Italy)-input data for seismic hazard assessment. Nat Hazards, 22, 3, 225-268. https://doi.org/10.1023 /A:1008149531980.

Hack, J.T. (1973): Stream-profiles analysis and stream-gradient index. Journal of Research of the U.S. Geological Survey, 1, 4, 421-429.

Hall, R. (2012): Late Jurassic-Cenozoic reconstructions of the Indonesian region and the Indian Ocean. Tectonophysics, 570, 571, 1-41. https:// doi.org/10.1016/j.tecto.2012. 04.021 .

Handayani, L., Arisbaya, I., Mukti,. M.M., Sudrajat, Y. (2021): Determining the origin of volcanic rocks in the mélange complex of Karangsambung based on the electrical resistivity imaging. Island Arc, 30, 12377, 1-10. https://doi. org/10.1111/iar.12377.

Harsolumakso, A. H. (1996): Status of Olistostrom in Luk Ulo Region, Central Java; a review of stratigraphy, age and deformation, National Seminar Collection Papers, 101-121. (in Indonesian).

Harsolumakso, A.H., Suparka M.E., Noeradi D., Kapid R, Zaim Y., Magetsari N.A., and Abdullah C.I. (1995): Characteristics of Melange Structure in Luk Ulo Area, Kebumen, Central Java, Proceedings of a One-Day Seminar on Geotechnology in Industrialization, PPPG-LIPI, Bandung, 190 - 215. (in Indonesian).

Hidayat E. (2010): Morphotectonic Analysis of Lembang Fault, West Java, Widya Research, Indonesian Institute of Sciences, 13, 2, 83-92. (in Indonesian).

Horton, R.E. (1945): Erosional Development of Stream and Their Drainage Basins: Hydrophysical Approach to Quantitative Morphology. Geological Society of America Bulletin 56.

Kadarusman, A., Massonne, H. J., Roermund, H. V., Permana, H., Munasri. (2007): P-T Evolution of Eclogites and Blueschists from the Lukulo Complex of Central Java, Indonesia. International Geology Review, 49, 329-356.

Keller, E. A. (1986): Investigation of Active Tectonics: Use of Surficial Earth Processes. In: Wallace, R. E., ed., Active Tectonics, Studies in Geophysics. National Academy Press, Washington DC. 136-147.

Keller, E. A., Pinter, N. (2002): Active Tectonics: Earthquakes, Uplift, and Landscape. Prentice Hall, New Jersey, 359 p.

Keller, E.A. and Pinter N. (1996): Active Tectonics (Earthquake, Uplift and Landscape), Prentise Hall, Upper Saddle River, New Jersey 07458.

Khayingshing, L., Surendra S. B., Girish C.K. (2015): Drainage response to active tectonics and evolution of tectonic geomorphology across the Himalayan Frontal Thrust, $\mathrm{Ku}-$ maun Himalaya. J. Geomorphology, 239, 58-72. 
Miyazaki, K., Sopaheluwakan, J., Zulkarnain, I., and Wakita, K. (1998): A jadeite - quartz - glaucophane rock from Karangsambung, Central Java, Indonesia. The Island Arc, 7, 223230. https://doi.org/10.1046/j.1440-1738.1998.00164.x.

Parkinson, C. D., Miyazaki, K., Wakita, K., Barber, A. J., and Carswell, D. A. (1998): An overview and tectonic synthesis of the pre-tertiary veryhigh-pressure metamorphic and associated rocks of Java, Sulawesi and Kalimantan, Indonesia. Island Arc, 7, 1-2, 184-200. https://doi.org/10. 1046/j.1440-1738.1998.00184.x.

Prasetyadi, C., Suparka, E.R., Harsolumakso, A.H., Sapiie, B. (2006): The Larangan Complex: A newly found Eocene tectonic melange rock in Karangsambung area, Central Java, Indonesia, Extended abstract International Sedimentological Congress, Fukuoka.

Prasetyadi, C. (2007): Tectonic evolution of Paleogene East Java, Dissertation of Geology Engineering Department, ITB, unpublished, 325 p. (in Indonesian).

Ramírez-Herrera, MT. (1998): Geomorphic assessment of active tectonics in the Acambay Graben, Mexican volcanic belt. Earth Surface Processes and Landforms, 23, 317-332.

Rockwell, T. K., Keller, E. A., Johnson, D. L. (1985): Tectonic Geomorphology of Alluvial Fans and Mountain Fronts near Ventura, California. In: Morisawa, M., ed., Tectonic Geomorphology. Proceedings of the 15th Annual Geomorphology Symposium. Allen and Unwin Publishers, Boston, MA. 183-207.

Saputra, A., Gomez, C., Delikostidis, I., Zawar, P., Reza, Hadmoko, D.S., Sartohadi. J. (2020): Preliminary identification of earthquake triggered multi-hazard and risk in Pleret Sub-District (Yogyakarta, Indonesia), Geo-spatial Information Science, 24, 2, 1-23. https://doi.org/10.1080/1 0095020.2020 .1801335 .

Satyana, A.H., and Purwaningsih M.E.M. (2002): Central Java Structural Indentation: A Strike-Slip Fault Segmentation, Indonesian Association of Ggeologists (IAGI) Yogyakarta - Central Java, 1-9. (in Indonesian).

Silva, P. G., Goy, J. L., Zazo, C., et al. (2003): Fault-Generated Mountain Fronts in Southeast Spain: Geomorphologic Assessment of Tectonic and Seismic Activity. Geomorphology, 50, 1-3, 203-225. https://doi.org/10.1016/s0169$555 \mathrm{x}(02) 00215-5$.

Singh, B. B., Afzal A., Khan A.R., Ahmad. (2016): Morphotectonic analysis of the Madhumati watershed, northeast Kashmir Valley, Arab J Geosci, 9, 390, 13-17.

Smyth, H. R., Hamilton, P. J., Hall, R., \& Kinny, P. D. (2007): The deep crust beneath Island arcs: Inherited zircons reveal a Gondwana continental fragment beneath East Java, Indonesia. Earth and Planetary Science Letters, 258, 269282. https://doi.org/10.1016/j.eps1.2007.03.044.

Sribudiyani, Nanang Muchsin, Rudy Ryacudu, Triwidiyo Kunto, Puji Astono, Indra Prasetya, Benyamin Sapiie, Sukendar Asikin, Agus H. Harsolumakso, Ivan Yulianto. (2003): The collision of the east java microplate and its implication for hydrocarbon occurrences in the east java basin, Proceedings Indonesian Petroleum Association, Twenty-Ninth Annual Convention \& Exhibition, 335-346.

Strahler, A.N. (1952): Hypsometric (area-altitude) analysis of erosional topography. Geological Society of America Bulletin 63, 1117-1142.
Subagio. (2008): Subsurface Geological Structure of the Kebumen Area Based on Analysis of Gravity and Geomagnetic Anomaly Patterns. Journal of Geological Resources, 18, 6, 391-407. (in Indonesian).

Sukiyah, E. (2009): Erosion Model of Quaternary Volcanic Landscapes in the Southern Bandung Basin. Dissertation, Padjadjaran University Postgraduate Program, Bandung, unpublished, 301 p. (in Indonesian).

Sukiyah, E. (2017): Geographical Information Systems, Concepts, and Applications in Quantitative Geomorphological Analysis, Unpad Press, ISBN 978-602-439239-0. 296 p. (in Indonesian).

Suparka, M.E. (1988): Study of petrology and chemical pattern of ophiolite complex of North Karangsambung Luh Ulo, Central Java, Geological evolution of Central Java, Dissertation of Geology Engineering Department, ITB, unpublished, 181 p. (in Indonesian).

Soeria-Atmadja, R., Maury, R. C., Bellon, H., Pringgoprawiro, H., Polve, M., and Priadi, B. (1994): Tertiary magmatic belts in Java. Journal of Southeast Asian Earth Sciences, 9, I/2, 13-27. https://doi.org/10. 1016/0743-9547(94)90062-0.

Tjia, H.D. (1966): Structural analyses of the Pre-Tertiary of the Lokulo area, Central Java, Ph.D dissertation, Contribut. From the Dept. of Geol., ITB, No. 63.

Trenc, N., Matoš, B., Velić, J., Perković, D. (2019): Application of GIS procedure for river terrace extraction from a LiDAR- based digital elevation model: the Sava River Valley NW of Zagreb, Croatia. The Mining-Geological-Petroleum Bulletin (Rudarsko-geološko-naftni zbornik), 34, 1, 59-70. https://doi.org/10.17794/rgn.2019.1.6.

Wakita, K. (2000): Cretaceous accretionary-collision complexes in central Indonesia, Journal of Asian Earth Sciences, 18, 739-749.

Wakita, K., Miyazaki, K., Sopaheluwakan, J., Zulkarnain I., Parkinson, C., Munasri. (1997): Cretaceous subduction complexes along the southeastern margin of Sundaland, Memoirs of the Geological Society of Japan, 48, 152-162.

Wakita, K., Munasri, Bambang, W. (1994): Cretaceous radiolarians from the Luk-Ulo Melange Complex in the Karangsambung area, Central Java, Indonesia, Journal SE Asian Sciences, 9, 29-43.

Yudhicara, Muslim, D., Sudradjat A. (2017): Geomorphic analysis in determining tectonic activity affected by Sumatra Fault in Liwa Region and its surrounding area, Lampung, Indonesia Indonesian Journal on Geosciences, 4, 193-208.

Zhijun Gong, Sheng-Hua Li, Bo Li. (2014): The evolution of a terrace sequence along the Manas River in the northern foreland basin of Tian Shan, China, as inferred from optical dating, Geomorphology, 213, 201-212.

\section{Web pages:}

URL 1: http://tides.big.go.id/DEMNAS/index.html\#Info

URL 2: https://earthquake.usgs.gov/earthquakes/map

URL 3: https://www.bmkg.go.id/gempabumi/katalog-gempabumi-signifikan.bmkg?lang=ID 


\section{SAŽETAK}

\section{Tektonska geomorfologija područja Karangsambung, središnja Java, Indonezija}

Područje Karangsambung na središnjoj Javi, u Indoneziji, ima složenu geološku građu kao posljedicu tektonske evolucije otoka Jave, prouzročenu subdukcijom indijsko-australske ploče ispod euroazijske tijekom krede i paleocena. Rezultat su različite geološke strukture i vrste stijena te njihov utjecaj na morfologiju terena. Iznos tektonske aktivnosti bilo je moguće odrediti tektonsko-geomorfološkim pristupom. Za geomorfičku obradbu podataka iskorišteni su digitalni model površine i geografski informacijski sustav. Uz to, geološki podatci također su uporabljeni za oblikovanje riječnih terasa. Izdvojeno je sedam geomorfičkih indeksa, kojima je izračunana najmlađa tektonska aktivnost. Za to je iskorišten indeks relativne tektonske aktivnosti područja. On se sastoji od omjera širine dna i visina doline, asimetrije drenažnoga bazena, indeksa gradijenta dužine rijeke, indeksa oblika bazena, sinusoidnosti čela planine, gustoće drenaže i hipsometrijskoga integrala, tj. krivulje. Indeks tektonske aktivnosti podijeljen je u četiri klase: klasu 1 (o \%) koja označava vrlo jaku aktivnost, klasu 2 (13\%) jaku, klasu 3 (56 \%) umjerenu i klasu 4 (31 \%) nisku aktivnost. Indeks je pokazao kako je istraživano područje moguće kategorizirati kao tektonski aktivno, gdje je oblikovana morfologija posljedica uglavnom tektonike, a ne erozije. Analiza geoloških podataka na izdignutim i deformiranim izdancima riječnih terasa pokazala je utjecaj neotektonike.

\section{Ključne riječi:}

geomorfički indeks, relativna tektonska aktivnost, neotektonika, Karangsambung

\section{Author's contribution}

Edi Hidayat (Ph.D. student, junior researcher, geological structure, neotectonic, and morphotectonic) was in charge of manuscript writing, sampling and measurements, and data analysis and gave possible conclusions of this research. Dicky Muslim (Dr., associate professor, engineering geology, neotectonic) was in charge of manuscript writing, morphotectonic and neotectonic analysis data, and overall manuscript structure. Zufialdi Zakaria (Dr., senior lecturer, engineering geology) was in charge of manuscript writing and took part in the data analysis. Haryadi Permana (Dr, senior researcher, tectonic) was in charge of the tectonic analysis. Dimas Aryo Wibowo (Magister, junior researcher, GIS) was in charge of the supported processing data and sampling measurements. 